\title{
Influence of sulfur on the fate of heavy metals during clinkerization
}

Bin Zhang ${ }^{1}$, Anna Bogush ${ }^{2}$, Jiangxiong Wei ${ }^{13^{*}}$, Tongsheng Zhang ${ }^{1,3}$, Weiting $\mathrm{Xu}^{1,3}$,

$$
\text { Qijun } \mathrm{Yu}^{1,3}
$$

1. School of Materials Science and Engineering, South China University of Technology, Guangzhou 510640, Guangdong, China

2. Centre for Resource Efficiency \& the Environment (CREE), Department of Civil, Environmental \& Geomatic Engineering (CEGE), University College London (UCL), Chadwick Building, Gower Street, London WC1E 6BT, UK

3. Guangdong Low Carbon Technologies Engineering Center for Building Materials, Guangzhou 510640, Guangdong, China

\begin{abstract}
The fate of heavy metals during clinkerization is of crucial significance to the solid waste utilization, environmental management, and sustainable development. This paper presents a laboratory scale simulation that aims to investigate the effects of sulfur on the fate of $\mathrm{Cu}, \mathrm{Pb}$, and $\mathrm{Cd}$ during clinkerization. The sulfur-bearing phases $\left(\mathrm{CaSO}_{4} \cdot 2 \mathrm{H}_{2} \mathrm{O}\right.$ and $\left.\mathrm{CaS}\right)$ and metal oxides were mixed with cement raw meal in appropriate ratios to produce clinkers. The volatilization and solidification of $\mathrm{Cu}, \mathrm{Pb}$ and Cd were investigated using atomic absorption spectrometry, thermogravimetric
\end{abstract}

* Corresponding author: jxwei@ scut.edu.cn, Tel.: +86 02087114137 
analysis, X-ray diffraction analyses, electron probe X-ray microanalysis, and scanning electron microscopy. The volatilization of $\mathrm{Cu}$ slightly increased in the temperature range $950^{\circ} \mathrm{C}-1450^{\circ} \mathrm{C}$ with addition of sulfur. Sulfur promotes the volatilization of $\mathrm{Pb}$ and $\mathrm{Cd}$ at the temperature from $950^{\circ} \mathrm{C}$ to $1250^{\circ} \mathrm{C}$ by decreasing the melting point of $\mathrm{PbO}$ and $\mathrm{CdO}$. Sulfur increased the solidification ability of clinker decreasing the volatilization ratio of $\mathrm{Pb}$ and $\mathrm{Cd}$ at the temperature of $1350-1450^{\circ} \mathrm{C}$ and $1450^{\circ} \mathrm{C}$, respectively. Both forms of sulfur $\left(\mathrm{CaSO}_{4} \cdot 2 \mathrm{H}_{2} \mathrm{O}\right.$ and $\left.\mathrm{CaS}\right)$ have similar effect on the $\mathrm{Cu} / \mathrm{Pb} / \mathrm{Cd}$ volatilization. Sulfur concentrated in interstitial phases of the clinkers mainly as $\mathrm{Ca}_{4} \mathrm{Al}_{6} \mathrm{O}_{12} \mathrm{SO}_{4}$ and $\mathrm{CaSO}_{4} . \mathrm{Cu}, \mathrm{Pb}$ and $\mathrm{Cd}$ were mainly solidified within interstitial phases of the clinkers forming solid solutions with the variable compositions. $\mathrm{Cu}$ was also present in alite and belite and as crystalline phases of $\mathrm{Ca}_{2} \mathrm{CuO}_{3}$ and $\mathrm{CaCu}_{2} \mathrm{O}_{3}$ in the clinkers. This research can help to improve understanding of the fate of heavy metals and provide a guideline for risk assessment during the co-processing of solid wastes in cement kiln.

Keywords: clinker, heavy metals, sulfur, volatilization, solidification, element speciation

\section{Introduction}

Due to the rapid development of modern industry and city, significant amount of solid wastes (SW) are being produced every day, for instance, 3.28 billion tons of industrial SW, 173 million tons of municipal solid waste (MSW) and 25 million tons of 
sludge were produced in China in 2016 [1]. About 77\% of the solid wastes were transported to the landfills and waste incineration facilities [2]. However, solid wastes can be considered as secondary raw fuels and/or materials in the cement industry, for example, in co-processing of solid wastes in the cement kiln [3-6]. By the implementation of co-processing, the natural resources can be saved and carbon dioxide emissions can be reduced [7-10]. Nevertheless, most of the solid wastes contain heavy metals that could be volatilized and move with flue gas into the atmosphere during clinkerization, polluting the environment and threatening human health [11-13]. Therefore, it is important to study the volatilization of heavy metals during coprocessing of solid wastes in the cement kiln.

The previous studies carried on heavy metal emissions from solid wastes coprocessing indicated that the fate of heavy metals strongly depended on the waste composition, particularly on the content of chlorine and sulfur in the solid wastes and cement raw meal $[14,15]$. The content of sulfur in the cement kiln is about $0.5 \mathrm{wt} \%$ to 2.0 wt.\%, that mainly come from raw fuels (e.g., coal) and materials (e.g., limestone containing sulfide minerals) combustion [16]. The content of sulfur in the cement kiln might increase due to co-processing of solid wastes with high content of sulfur. Therefore, the detailed investigation of the effect of sulfur on the fate of heavy metals in co-processing of solid wastes in the cement kiln are required. Chan et al. [17], Smith [18], and Nowak et al. $[19,20]$ focused on the effect of sulfur (such as $\mathrm{Na}_{2} \mathrm{SO}_{4}$ and $\mathrm{K}_{2} \mathrm{SO}_{4}$ ) on the volatilization of heavy metals during the burning of solid wastes. However, the temperatures investigated were relatively low $\left(<1200^{\circ} \mathrm{C}\right)$ comparing to the 
Portland cement clinker production $\left(\mathrm{T}=1450^{\circ} \mathrm{C}\right)$. Moreover, cations from the sulfates such as $\mathrm{Na}^{+}$and $\mathrm{K}^{+}$might influence on the clinkering process, volatilization and solidification of heavy metals [21, 22].

Heavy metals like $\mathrm{Cu}, \mathrm{Pb}$, and $\mathrm{Cd}$ commonly exist in the solid wastes such as $\mathrm{Pb}$ Zn slag, residues from MSW incineration facilities and sewage sludge [23-25]. Heavy metals might volatilize and move with flue gas into the atmosphere. $\mathrm{Pb}$ and $\mathrm{Cd}$ are easy to volatilize during the thermal treatment process of solid wastes [17, 20, 26-27]. $\mathrm{CuO}$ is known to act as flux and/or mineralizer in the clinkerization because it decreases the melting temperature considerably and favours the combination of free lime [20,28].

In this research, the effects of sulfur on the fate of $\mathrm{Cu}, \mathrm{Pb}$, and $\mathrm{Cd}$ was emphasized and the binary system of clinker-heavy metal in the study of co-processing of SW in cement kiln was developed to ternary system of clinker-heavy metal-sulfur, which is more coincident with the condition of co-processing of SW in cement kiln. Two sources of sulfur as gypsum $\left(\mathrm{CaSO}_{4} \cdot 2 \mathrm{H}_{2} \mathrm{O}\right)$ and calcium sulfide $(\mathrm{CaS})$ were used in our experiments. The relationships among sulfur sources, volatilization and solidification of $\mathrm{Cu} / \mathrm{Pb} / \mathrm{Cd}$, and mineral phases of clinker were investigated. This paper can help to improve understanding of the fate of heavy metals in presence of sulfur and provide a guideline for risk assessment during the utilization of solid wastes in cement kiln.

\section{Materials and method}

\subsection{Materials}

Cement raw materials such as $\mathrm{CaCO}_{3}, \mathrm{SiO}_{2}, \mathrm{Al}_{2} \mathrm{O}_{3}$, and $\mathrm{Fe}_{2} \mathrm{O}_{3}$, were supplied by 
pure chemical reagent in order to eliminate the effects of impurity ions such as $\mathrm{Na}^{+}, \mathrm{K}^{+}$, and $\mathrm{Cl}^{-}$in the industrial raw materials. $\mathrm{Cu}, \mathrm{Pb}$, and $\mathrm{Cd}$ were added to the raw mixes as $\mathrm{CuO}, \mathrm{PbO}$ and $\mathrm{CdO}$, respectively. $\mathrm{S}$ was added in two different species as sulfate (gypsum - $\left.\mathrm{CaSO}_{4} \cdot 2 \mathrm{H}_{2} \mathrm{O}\right)$ and sulfide $(\mathrm{CaS})$.

\subsection{Experimental procedure}

The phase composition of cement clinkers was controlled by Bogue method (see Eq. (1) - (3)) [28]. Lime saturation ratio (KH), silica ratio (SM), and alumina ratio (IM) were designed as $0.9,2.5$, and 1.6 , respectively. The theoretical mineral composition was calculated to be $56 \%$ of alite $\left(\mathrm{C}_{3} \mathrm{~S}\right), 20 \%$ of belite $\left(\mathrm{C}_{2} \mathrm{~S}\right), 8.6 \%$ of aluminate $\left(\mathrm{C}_{3} \mathrm{~A}\right)$, and $10 \%$ of ferrite $\left(\mathrm{C}_{4} \mathrm{AF}\right)$. Cement raw meals with 2.0 wt.\% of $\mathrm{Cu}, \mathrm{Pb}$, or $\mathrm{Cd}$ were prepared and sulfur concentration was varied (0.5 wt.\%, $1.0 \mathrm{wt} . \%, 1.5 \mathrm{wt} . \%$, and 2.0 wt.\%). Table 1 lists the formulated mixtures.

Lime saturation ratio $(\mathrm{KH})=\frac{\mathrm{CaO}-1.65 \mathrm{Al}_{2} \mathrm{O}_{3}-0.35 \mathrm{Fe}_{2} \mathrm{O}_{3}}{2.8 \mathrm{SiO}_{2}}$

Silica ratio $(\mathrm{SM})=\frac{\mathrm{SiO}_{2}}{\mathrm{Al}_{2} \mathrm{O}_{3}+\mathrm{Fe}_{2} \mathrm{O}_{3}}$

Alumina ratio $(\mathrm{IM})=\frac{\mathrm{Al}_{2} \mathrm{O}_{3}}{\mathrm{Fe}_{2} \mathrm{O}_{3}}$

\section{Table 1}

The formulated mixtures with $\mathrm{Cu}, \mathrm{Pb}, \mathrm{Cd}$, and sulfur (wt. \%).

\begin{tabular}{lllll}
\hline ID. & $\mathrm{Cu}$ & $\mathrm{Pb}$ & $\mathrm{Cd}$ & $\mathrm{CaSO}_{4} \cdot 2 \mathrm{H}_{2} \mathrm{O} / \mathrm{CaS}(\mathrm{S}:$ wt. \%) \\
\hline $\mathrm{S}_{\mathrm{Cu}-\mathrm{S}-0}$ & 2.0 & 0 & 0 & 0 \\
$\mathrm{~S}_{\mathrm{Cu}-\mathrm{CaSO} 4-0.5} / \mathrm{S}_{\mathrm{Cu}-\mathrm{CaS}-0.5}$ & 2.0 & 0 & 0 & 0.5 \\
$\mathrm{~S}_{\mathrm{Cu}-\mathrm{CaSO} 4-1.0} / \mathrm{S}_{\mathrm{Cu}-\mathrm{CaS}-1.0}$ & 2.0 & 0 & 0 & 1.0 \\
$\mathrm{~S}_{\mathrm{Cu}-\mathrm{CaSO} 4-1.5} / \mathrm{S}_{\mathrm{Cu}-\mathrm{CaS}-1.5}$ & 2.0 & 0 & 0 & 1.5 \\
& & & &
\end{tabular}




\begin{tabular}{|c|c|c|c|c|}
\hline $\mathrm{S}_{\mathrm{Cu}-\mathrm{CaSO} 4-2.0} / \mathrm{S}_{\mathrm{Cu}-\mathrm{CaS}-2.0}$ & 2.0 & 0 & 0 & 2.0 \\
\hline $\mathrm{S}_{\mathrm{Pb}-\mathrm{S}-0}$ & 0 & 2.0 & 0 & 0 \\
\hline $\mathrm{S}_{\mathrm{Pb}-\mathrm{CaSO} 4-0.5} / \mathrm{S}_{\mathrm{Pb}-\mathrm{CaS}-0.5}$ & 0 & 2.0 & 0 & 0.5 \\
\hline $\mathrm{S}_{\mathrm{Pb}-\mathrm{CaSO} 4-1.0} / \mathrm{S}_{\mathrm{Pb}-\mathrm{CaS}-1.0}$ & 0 & 2.0 & 0 & 1.0 \\
\hline $\mathrm{S}_{\mathrm{Pb}-\mathrm{CaSO}} 4-1.5 / \mathrm{S}_{\mathrm{Pb}-\mathrm{CaS}-1.5}$ & 0 & 2.0 & 0 & 1.5 \\
\hline $\mathrm{S}_{\mathrm{Pb}-\mathrm{CaSO} 4-2.0} / \mathrm{S}_{\mathrm{Pb}-\mathrm{CaS}-2.0}$ & 0 & 2.0 & 0 & 2.0 \\
\hline $\mathrm{S}_{\mathrm{Cd}-\mathrm{S}-0}$ & 0 & 0 & 2.0 & 0 \\
\hline $\mathrm{S}_{\mathrm{Cd}-\mathrm{CaSO}} 4-0.5 / \mathrm{S}_{\mathrm{Cd}-\mathrm{CaS}-0.5}$ & 0 & 0 & 2.0 & 0.5 \\
\hline $\mathrm{S}_{\mathrm{Cd}-\mathrm{CaSO}} 4-1.0 / \mathrm{S}_{\mathrm{Cd}-\mathrm{CaS}-1.0}$ & 0 & 0 & 2.0 & 1.0 \\
\hline $\mathrm{S}_{\mathrm{Cd}-\mathrm{CaSO}} 4-1.5 / \mathrm{S}_{\mathrm{Cd}-\mathrm{CaS}-1.5}$ & 0 & 0 & 2.0 & 1.5 \\
\hline $\mathrm{S}_{\mathrm{Cd}-\mathrm{CaSO} 4-2.0} / \mathrm{S}_{\mathrm{Cd}-\mathrm{CaS}-2.0}$ & 0 & 0 & 2.0 & 2.0 \\
\hline
\end{tabular}

The formulated mixtures were thoroughly blended and homogenized in a mechanical planetary mixer. Then each mixture was mixed with $8 \%$ of absolute ethanol and pelletized into $\emptyset 10 \times 50 \mathrm{~mm}$ cylindrical bar under $40 \mathrm{MPa}$. Each pellet was calcined from room temperature to the designated temperature at a heating rate of $10{ }^{\circ} \mathrm{C} / \mathrm{min}$. When the furnace reached designated temperature, it was maintained for $45 \mathrm{~min}$ and then the clinkers were cooled quickly in air to the room temperature [28].

\subsection{Analytical methods}

The clinkers were grounded into fine powder. The clinker samples were dissolved using an acid mixture of hydrogen peroxide $\left(\mathrm{H}_{2} \mathrm{O}_{2}\right)$, aqua regia, and hydrogen fluoride (HF) in a volume ratio of 2:5:2 in a microwave digestion system (ZEROM, China). The concentrations of $\mathrm{Cu}, \mathrm{Pb}$ and $\mathrm{Cd}$ in the solutions were analyzed by flame atomic absorption spectrometry (AAS, Analytik Jena AG, Germany). The duplicate measurements were carried out, and the average values were used to calculate the volatilization percentage according to Eq. (4): 
$H=\left\{1-\frac{K}{S /(1-L O I)}\right\} \times 100 \%$

Where, $\mathrm{H}$ is the volatilization ratio of $\mathrm{Cu}, \mathrm{Pb}$ or $\mathrm{Cd} ; \mathrm{K}(\mathrm{mg} / \mathrm{kg})$ is the content of $\mathrm{Cu}, \mathrm{Pb}$ or $\mathrm{Cd}$ in the clinker; $\mathrm{S}(\mathrm{mg} / \mathrm{kg})$ is the content of $\mathrm{Cu}, \mathrm{Pb}$ or $\mathrm{Cd}$ in raw materials; and LOI represents the loss on ignition.

The distribution of $\mathrm{Cu}, \mathrm{Pb}$ and $\mathrm{Cd}$ in the clinker phases was investigated on the polished sections by electron probe micro-analysis (EPMA-1600, Shimadzu, Japan). The measurement was conducted with an acceleration voltage of $15.0 \mathrm{kV}$ and an electron beam diameter of $1 \mu \mathrm{m}$. The morphology of the clinkers and element analyses were investigated by scanning electron microscopy (SEM, EVO 18, Carl Zeiss, Germany) equipped with energy-dispersive X-ray spectroscopy (EDS, Oxford Instrument INCAx-sigth EDS-system). SEM/EDS analyses were performed with a 20 $\mathrm{kV}$ accelerating voltage.

Thermogravimetric analysis (TG) was used to investigate the influence of sulfur on the volatilization temperature of heavy metals. TG curves were obtained using a NETZSCH STA 449F3 instrument. TG analysis was conducted using about $20 \mathrm{mg}$ of sample (chemical reagent) in alumina pans with an air purge gas flow rate of 100 $\mathrm{mL} / \mathrm{min}$, equilibration at $30^{\circ} \mathrm{C}$ for $10-15 \mathrm{~min}$, followed by a heating rate of $10^{\circ} \mathrm{C} / \mathrm{min}$ from $30^{\circ} \mathrm{C}$ to $1250^{\circ} \mathrm{C}$ (for $\mathrm{CaSO}_{4} \cdot 2 \mathrm{H}_{2} \mathrm{O}$ - up to $1400^{\circ} \mathrm{C}$ ).

The mineralogical compositions of the samples were determined by X-ray diffraction analysis (Bruker D8). This diffractometer is equipped with $\mathrm{Cu} K \alpha(\lambda=1.5406$ $\AA, 40 \mathrm{kV}$ and $40 \mathrm{~mA}$ ). All patterns were scanned over the range $5^{\circ}<2 \theta<70^{\circ}$ using a step size of $0.02^{\circ}$ and a count time of $0.2 \mathrm{~s}$. 
Selective dissolution method was used to separate silicate and interstitial phases of the clinkers [29].

\section{Results and discussion}

\subsection{Effect of sulfur and temperature on the volatilization of $\mathrm{Cu}, \mathrm{Pb}$, and $\mathrm{Cd}$}

Figure 1 to 3 show the results obtained for $\mathrm{Cu}, \mathrm{Pb}$, and $\mathrm{Cd}$ volatilization with the addition of $\mathrm{CaSO}_{4} \cdot 2 \mathrm{H}_{2} \mathrm{O}$ and $\mathrm{CaS}$ at different temperatures. Without addition of sulfur, the volatilization ratio of $\mathrm{Cu}$ (Figure 1) increased from $6.0 \%$ to $20 \%$ with increasing the temperature from $950^{\circ} \mathrm{C}$ to $1450^{\circ} \mathrm{C}$. However, the $\mathrm{Cu}$ volatilization slightly increased $(\sim 10 \%)$ with increasing sulfur content.
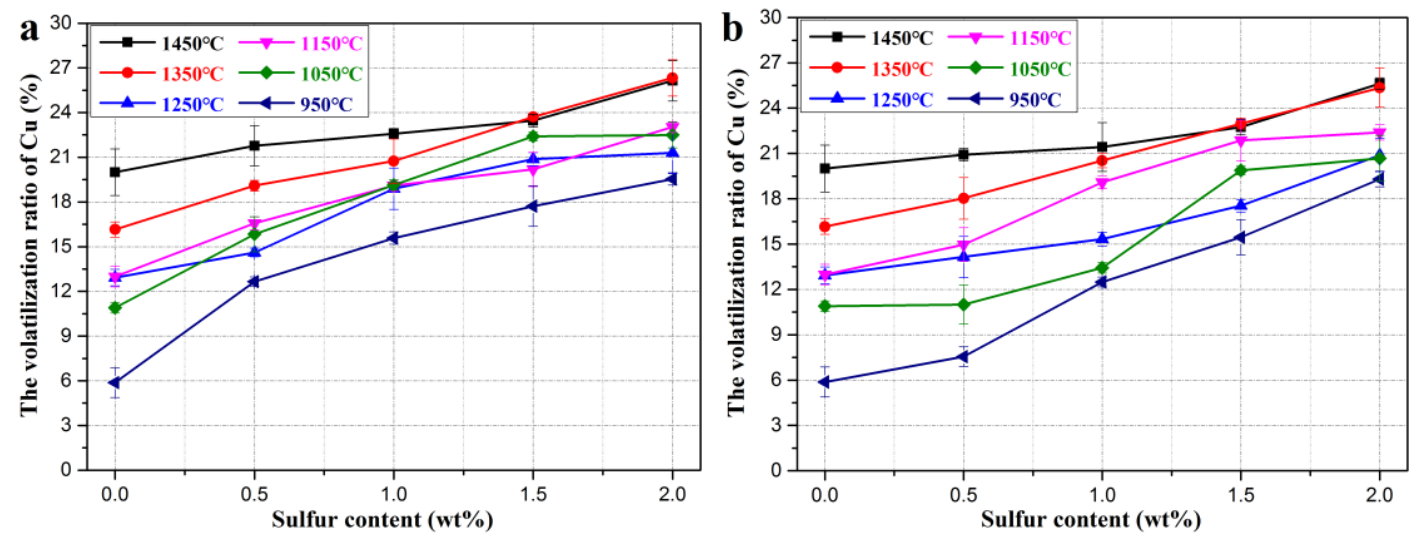

Fig. 1. Volatilization of $\mathrm{Cu}$ with sulfur addition: a) $\mathrm{CaSO}_{4} \cdot 2 \mathrm{H}_{2} \mathrm{O}$; b) $\mathrm{CaS}$.

Figure 2 shows that the volatilization ratio of $\mathrm{Pb}$ increased from $13.4 \%$ to $86.2 \%$ with increasing the temperature from $950^{\circ} \mathrm{C}$ to $1450^{\circ} \mathrm{C}$ without sulfur addition. The volatilization ratio of $\mathrm{Pb}$ slightly increased $(\sim 15 \%)$ with increasing $\mathrm{CaSO}_{4} \cdot 2 \mathrm{H}_{2} \mathrm{O}$ content at the temperature of $950^{\circ} \mathrm{C}, 1050^{\circ} \mathrm{C}, 1150^{\circ} \mathrm{C}$ and $1250^{\circ} \mathrm{C}$. However, when the temperature is higher than $1250^{\circ} \mathrm{C}$, the volatilization ratio of $\mathrm{Pb}$ decreased with 
increasing amount of $\mathrm{CaSO}_{4} \cdot 2 \mathrm{H}_{2} \mathrm{O}$. The significant decrease of $\mathrm{Pb}$ volatilization was observed at $1350^{\circ} \mathrm{C}(20.2 \%)$ and $1450^{\circ} \mathrm{C}(33.4 \%)$ with the addition of $2.0 \mathrm{wt} . \%$ of sulfur comparing to the reference sample.
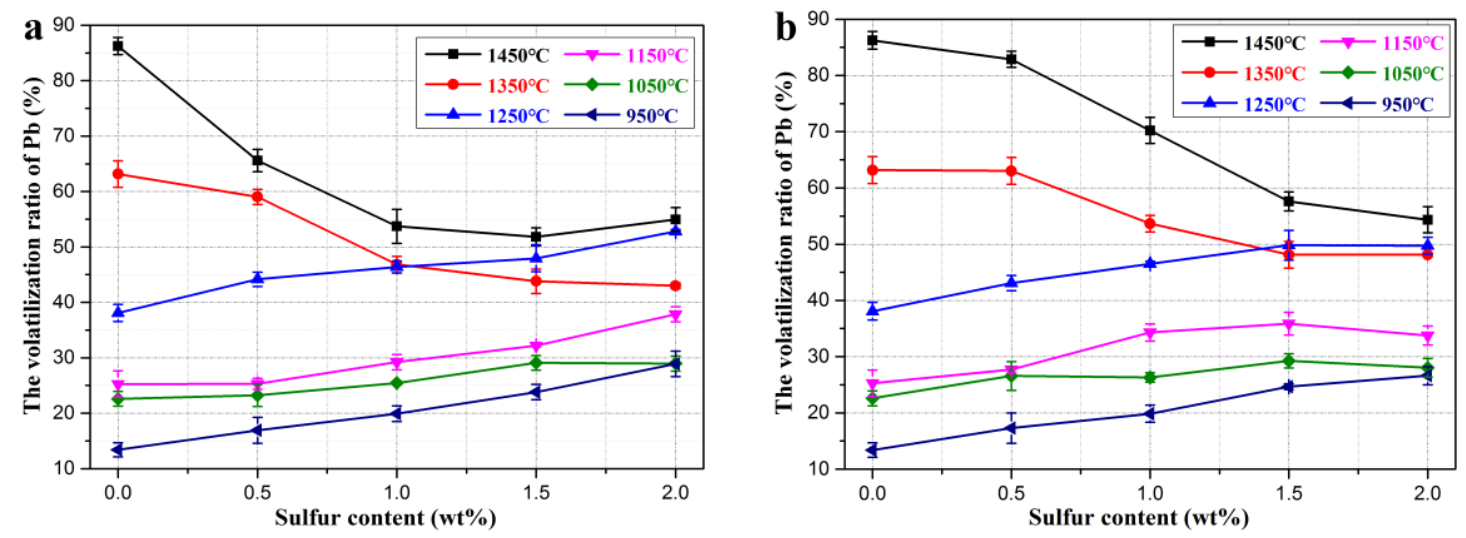

Fig. 2. Volatilization of $\mathrm{Pb}$ with sulfur addition: a) $\mathrm{CaSO}_{4} \cdot 2 \mathrm{H}_{2} \mathrm{O}$; b) $\mathrm{CaS}$.

The volatilization ratio of $\mathrm{Cd}$ increased from $23.9 \%$ to $59.4 \%$ with increasing the temperature from $950^{\circ} \mathrm{C}$ to $1450^{\circ} \mathrm{C}$ without sulfur addition (Figure 3). The volatilization ratio of $\mathrm{Cd}$ increased slightly $(\sim 12 \%)$ with increasing $\mathrm{CaSO}_{4} \cdot 2 \mathrm{H}_{2} \mathrm{O}$ content at the temperature of $950^{\circ} \mathrm{C}, 1050^{\circ} \mathrm{C}, 1150^{\circ} \mathrm{C}, 1250^{\circ} \mathrm{C}$ and $1350^{\circ} \mathrm{C}$. However, at the temperature of $1450^{\circ} \mathrm{C}$, the volatilization ratio of $\mathrm{Cd}$ decreased by $21.9 \%$, with the addition of 2.0 wt.\% of sulfur, compared the reference sample.
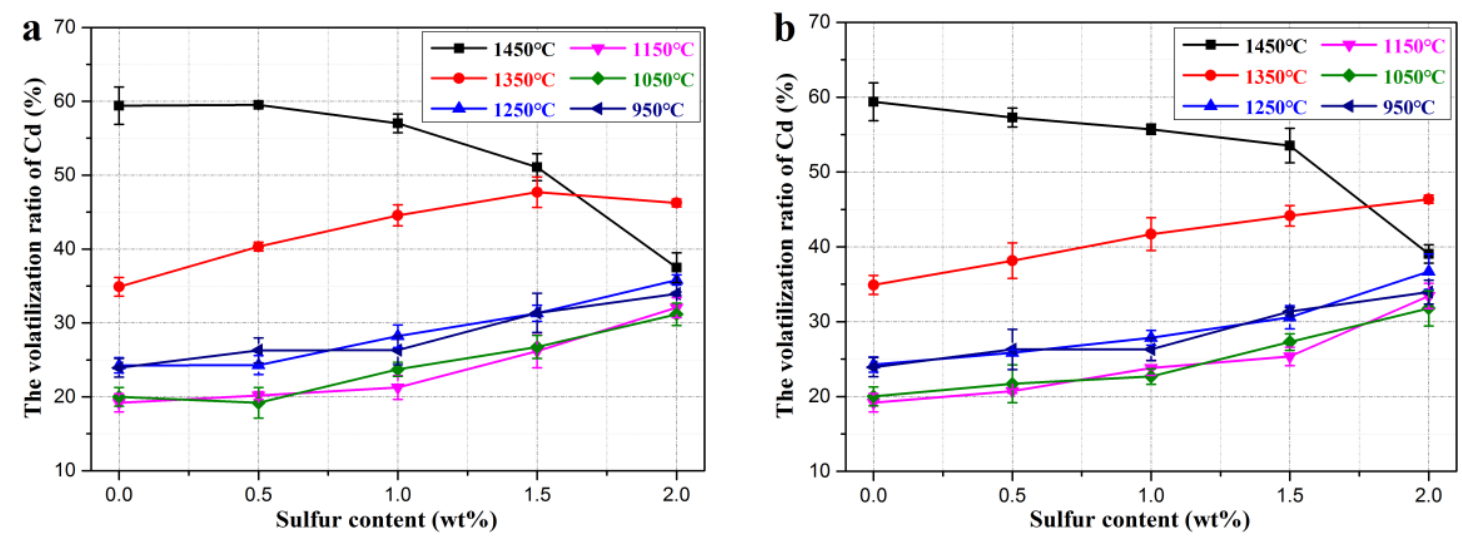

Fig. 3. Volatilization of $\mathrm{Cd}$ with sulfur addition: a) $\mathrm{CaSO}_{4} \cdot 2 \mathrm{H}_{2} \mathrm{O}$; b) $\mathrm{CaS}$. 
Heavy metals were classified as volatile $(\mathrm{Pb}$ and $\mathrm{Cd})$, semi-volatile $(\mathrm{Zn}, \mathrm{Sb}$, and $\mathrm{Se})$, and non-volatile ( $\mathrm{Cr}, \mathrm{Cu}, \mathrm{Ni}, \mathrm{As}, \mathrm{Mn}$, and $\mathrm{Co}$ ) elements [30]. Also, the melting and boiling temperatures of $\mathrm{CuO}\left(1026^{\circ} \mathrm{C}\right.$ and $\left.2000^{\circ} \mathrm{C}\right)$ are higher than that of $\mathrm{PbO}\left(888^{\circ} \mathrm{C}\right.$ and $\left.1535^{\circ} \mathrm{C}\right)$ and $\mathrm{CdO}\left(900^{\circ} \mathrm{C}\right.$ and $\left.1385^{\circ} \mathrm{C}\right)$, respectively. Therefore, $\mathrm{Pb}$ and $\mathrm{Cd}$ should have a higher volatilization ratio than $\mathrm{Cu}$ during clinkerization that was observed in our investigation. Sulfur in cement raw meal act as flux/mineralizer lowering the temperature of the liquid phase formation, increase the amount of the melt, and decrease the viscosity and the surface tension of the melt $[31,32]$. Lowering the surface tension and the viscosity of the melt, normally formed at above $1338^{\circ} \mathrm{C}$ (an invariant point; [33]), can increase the diffusivity of the clinkering species (including Pb-bearing and Cd-bearing species) and therefore promote the solidification of $\mathrm{Pb}$ and $\mathrm{Cd}$. According to Taylor [28, 34], Herfort et al. [35] and Wang et al. [36], sulfur dissolved in the melt can affect the acid-base equilibrium $\left[\mathrm{MeO}_{4}\right]^{5-} \leftrightarrow\left[\mathrm{MeO}_{6}\right]^{9-}$ of the amphoteric elements (Me: $\mathrm{Al}^{3+}$ and $\mathrm{Fe}^{3+}$ ). The displacement of this reaction to the left favors the formation of a network built from $\left[\mathrm{MeO}_{4}\right]^{5-}$ and silicon tetrahedra that leads to the increase of the melt viscosity, while $\left[\mathrm{MeO}_{6}\right]^{9-}$ is more mobile and promotes the decrease of the viscosity surface tension of the melt. These effects will promote the reaction among mineral phases and heavy metals. The more sulfur addition, the greater transformation degree of $\left[\mathrm{MeO}_{4}\right]^{5-}$ to $\left[\mathrm{MeO}_{6}\right]^{9-}$, and then the greater effect of sulfur on the volatilization/solidification of $\mathrm{Pb}$ and $\mathrm{Cd}$ will be observed. Therefore, the mineral phases of clinker might solidify more $\mathrm{Pb}$ and $\mathrm{Cd}$, and their volatilization ratio decreased 
when the temperature is higher than $1350^{\circ} \mathrm{C} . \mathrm{CuO}$ is hard to volatilize and might act as as flux/mineralizer itself. Therefore, the effect of sulfur on the $\mathrm{Cu}$ volatilization is not obvious.

Before the appearance of liquid phase during clinkerization (the temperature is lower than $1338^{\circ} \mathrm{C}$ ), the effects of sulfur on the volatilization of heavy metals were caused by decreasing the volatilization temperature of heavy metals, that will be confirmed in Section 3.2.

It can be seen from Figure 1 (b) to Figure 3 (b) that the effect of $\mathrm{CaS}$ on the volatilization of $\mathrm{Cu}, \mathrm{Pb}$, and $\mathrm{Cd}$ is similar to that of $\mathrm{CaSO}_{4} \cdot 2 \mathrm{H}_{2} \mathrm{O}$. The reason is that $\mathrm{CaS}$ might be oxidized to $\mathrm{CaSO}_{4}$ at the temperature around $700^{\circ} \mathrm{C}[37,38]$. The chemical reactions (1) - (5) might occur during the process of oxidation. However, the equation (1) is the main oxidation reaction due to the lowest Gibbs free energy under $700^{\circ} \mathrm{C}$ (Figure 4) [37, 38]. During the preparation of clinker, most of CaS was oxidized to $\mathrm{CaSO}_{4}$ around $700^{\circ} \mathrm{C}$ and the mineral phases formation of clinker is higher than $1000^{\circ} \mathrm{C}$. Besides, $\mathrm{CaS}$ is not reacting with heavy meal below the temperature of $700^{\circ} \mathrm{C}$. Namely, the mechanism of the effects of $\mathrm{CaS}$ on the volatilization and solidification of $\mathrm{Cu} / \mathrm{Pb} / \mathrm{Cd}$ is the same as $\mathrm{CaSO}_{4}$.

$$
\begin{aligned}
& \mathrm{CaS}+2 \mathrm{O}_{2}(g)=\mathrm{CaSO}_{4} \\
& \mathrm{CaS}+3 \mathrm{CaSO}_{4}=4 \mathrm{CaO}+4 \mathrm{SO}_{2}(g) \\
& \mathrm{CaS}+3 / 2 \mathrm{O}_{2}(\mathrm{~g})=\mathrm{CaO}+\mathrm{SO}_{2}(g) \\
& \mathrm{CaO}+2 \mathrm{SO}_{2}+1 / 2 \mathrm{O}_{2}(g)=\mathrm{CaSO}_{4} \\
& \mathrm{CaS}+2 \mathrm{SO}_{2}=\mathrm{CaSO}_{4}+2 \mathrm{~S}
\end{aligned}
$$




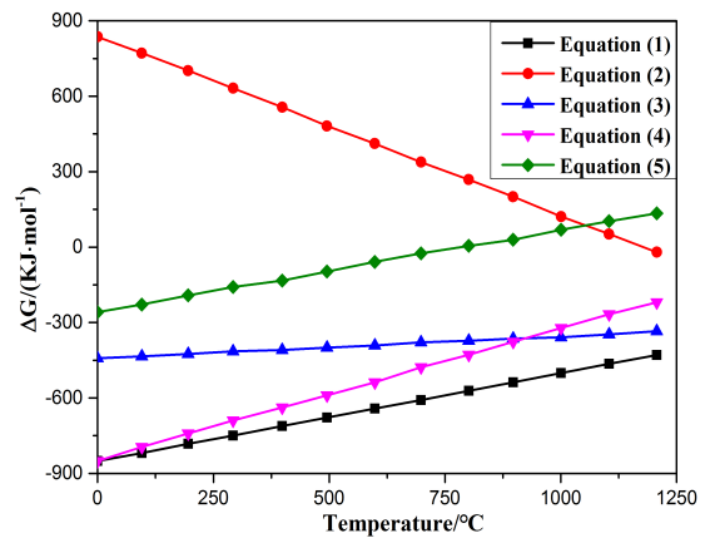

Fig. 4. Relationship between standard Gibbs free energy and temperatures of the equations (1) - (5) [37, 38].

\subsection{Effects of sulfur on the volatilization temperatures of $\mathrm{Cu}, \mathrm{Pb}$, and $\mathrm{Cd}$}

The results from thermogravimetric analysis are shown in Figure 5. The TG curves of gypsum showed the mass losses in the temperature range from around $150^{\circ} \mathrm{C}$ to $700^{\circ} \mathrm{C}$ due to dehydration of that mineral. Gypsum start decomposing at $1200^{\circ} \mathrm{C} . \mathrm{Cu}, \mathrm{Pb}$, and $\mathrm{Cd}$ start volatilizing at $1015^{\circ} \mathrm{C}, 940^{\circ} \mathrm{C}$, and $1070^{\circ} \mathrm{C}$, respectively. The addition of corresponding content of sulfur leads to decrease the volatilization temperatures of $\mathrm{Cu}$, $\mathrm{Pb}$, and $\mathrm{Cd}$ by $40^{\circ} \mathrm{C}, 65^{\circ} \mathrm{C}$, and $35^{\circ} \mathrm{C}$, respectively. Therefore, the sulfur has a positive effect on the volatilization of $\mathrm{Cu}, \mathrm{Pb}$, and $\mathrm{Cd}$ at the temperatures $<1250^{\circ} \mathrm{C}$, that confirmed the results in Section 3.1. $\mathrm{CaSO}_{4} \cdot 2 \mathrm{H}_{2} \mathrm{O}$ dehydrated at the temperature around $150^{\circ} \mathrm{C}$ and $700^{\circ} \mathrm{C}$ forming $\mathrm{CaSO}_{4}$ and the most of $\mathrm{CaS}$ was oxidized to $\mathrm{CaSO}_{4}$ around $700^{\circ} \mathrm{C} . \mathrm{CaSO}_{4}$ can act as mineralizer/flux changing the thermodynamic stability of $\mathrm{CuO} / \mathrm{PbO} / \mathrm{CdO}$ and, therefore, lowering their volatilization temperature. 

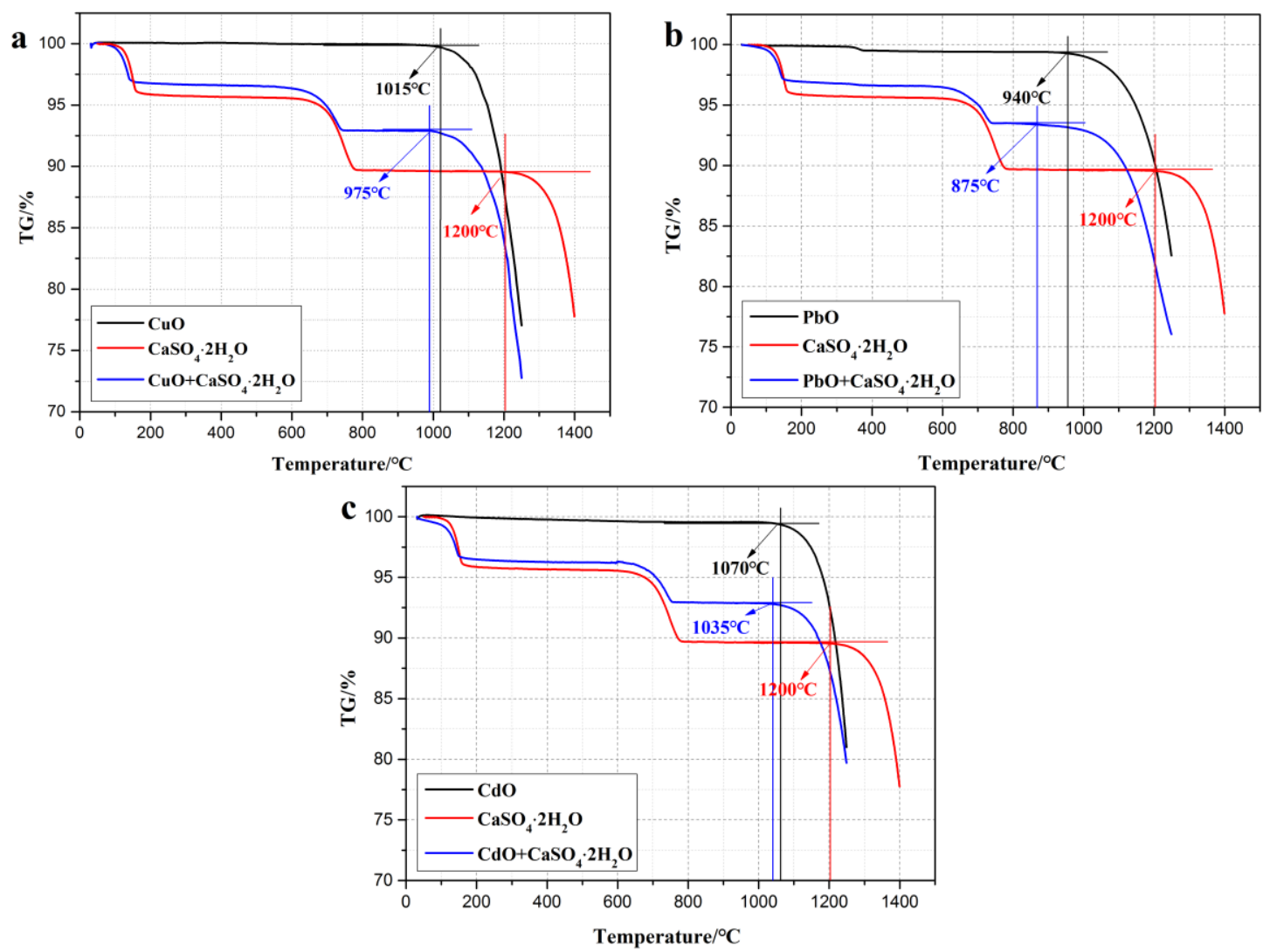

Fig. 5. TG curves of $\mathrm{CuO}, \mathrm{PbO}$, or $\mathrm{CdO}$ with/without $\mathrm{CaSO}_{4} \cdot 2 \mathrm{H}_{2} \mathrm{O}$ : a) $\mathrm{CuO}$

with/without $\mathrm{CaSO}_{4} \cdot 2 \mathrm{H}_{2} \mathrm{O}$; b) $\mathrm{PbO}$ with/without $\mathrm{CaSO}_{4} \cdot 2 \mathrm{H}_{2} \mathrm{O}$; c) $\mathrm{Cd}$ with/without $\mathrm{CaSO}_{4} \cdot 2 \mathrm{H}_{2} \mathrm{O}$.

\subsection{Sulfur speciation in clinker}

The XRD patterns of $\mathrm{S}_{\mathrm{Cu}-\mathrm{CaSO} 4-2.0}, \mathrm{~S}_{\mathrm{Pb}-\mathrm{CaSO} 4-2.0}$, and $\mathrm{S}_{\mathrm{Cd}-\mathrm{CaSO4-2.0}}$ samples sintered at $1450^{\circ} \mathrm{C}$ and their corresponding silicate and interstitial phases based on the selective dissolution method are shown in Figures 6-8. $\mathrm{CaSO}_{4}$ (mainly for the $\mathrm{S}$ additions 1.52.0 wt.\%) and $\mathrm{Ca}_{4} \mathrm{Al}_{6} \mathrm{O}_{12} \mathrm{SO}_{4}$, formed during clinkering process, were concentrated in the interstitial phases of the clinker. The content of $\mathrm{C}_{3} \mathrm{~A}$ and $\mathrm{C}_{4} \mathrm{AF}$ in the clinker decreased but sulfoaluminate $\left(\mathrm{Ca}_{4} \mathrm{Al}_{6} \mathrm{O}_{12} \mathrm{SO}_{4}\right)$ increased with increasing addition of sulfur. It was reported by Zhao [39] and Ma [40] that the calcium sulphoaluminate 
$\left(\mathrm{Ca}_{4} \mathrm{Al}_{4} \mathrm{O}_{12} \mathrm{SO}_{4}\right)$ was formed between the temperature of $1300^{\circ} \mathrm{C}$ and $1350^{\circ} \mathrm{C}$ in the system of $\mathrm{CaCO}_{3}-\mathrm{SiO}_{2}-\mathrm{Al}_{2} \mathrm{O}_{3}-\mathrm{Fe}_{2} \mathrm{O}_{3}-\mathrm{CaSO}_{4}$. When the temperature is higher than $1350^{\circ} \mathrm{C}, \mathrm{Ca}_{4} \mathrm{Al}_{4} \mathrm{O}_{12} \mathrm{SO}_{4}$ start to decompose to $\mathrm{C}_{3} \mathrm{~A}$ and $\mathrm{CaSO}_{4}$. Therefore, the main speciation of sulfur in clinker were $\mathrm{CaSO}_{4}$ and $\mathrm{Ca}_{4} \mathrm{Al}_{4} \mathrm{O}_{12} \mathrm{SO}_{4}$. Besides, the formation of $\mathrm{Ca}_{4} \mathrm{Al}_{4} \mathrm{O}_{12} \mathrm{SO}_{4}$ consumed some $\mathrm{Al}$, which result in the decreased content of $\mathrm{C}_{3} \mathrm{~A}$ and $\mathrm{C}_{4} \mathrm{AF}$.
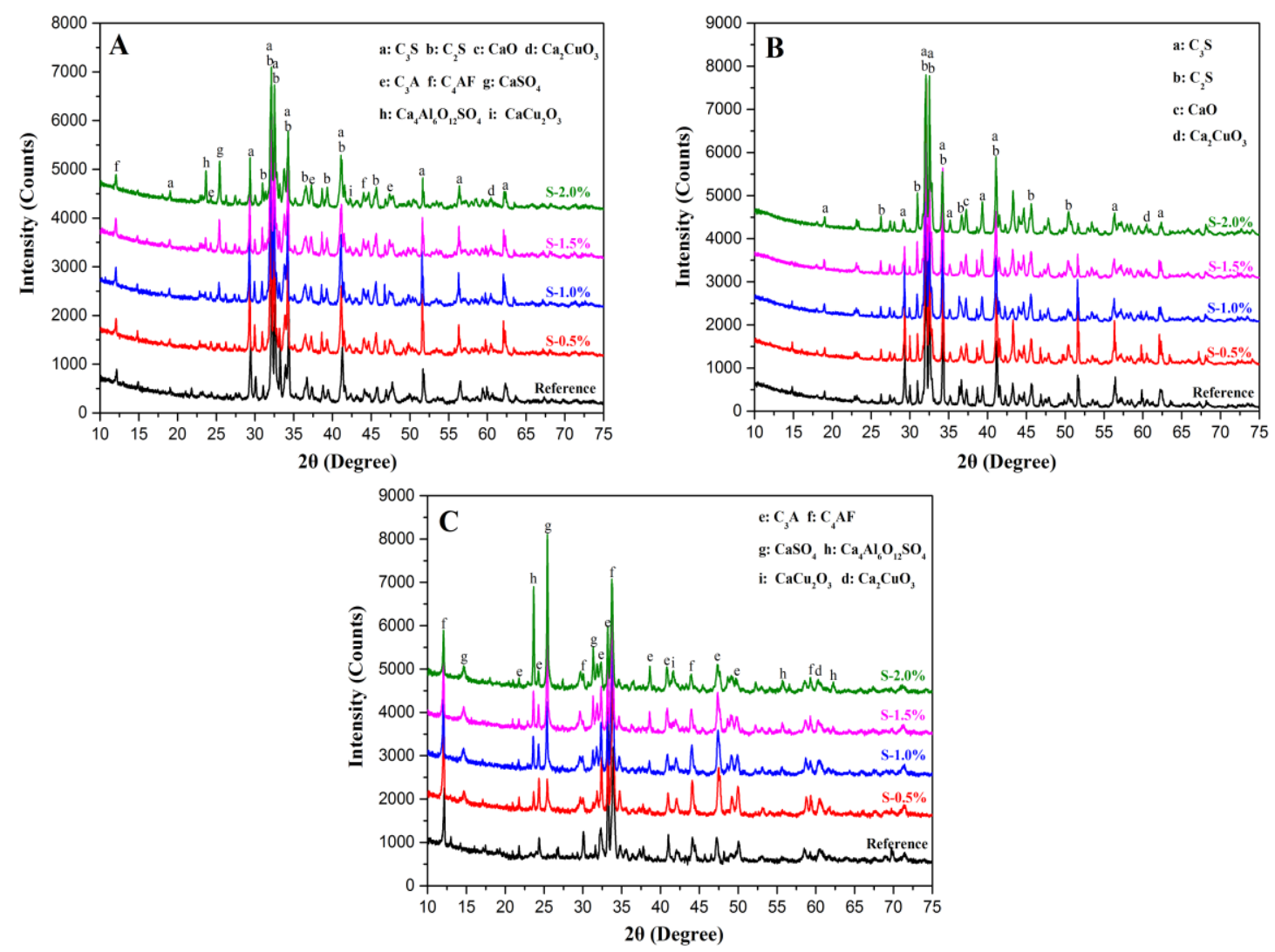

Fig. 6. XRD patterns of $\mathrm{S}_{\mathrm{Cu}-\mathrm{CaSO}-2.0}$ sample sintered at $1450^{\circ} \mathrm{C}$ : A) Clinker; B) Silicate phase; C) Interstitial phase. 

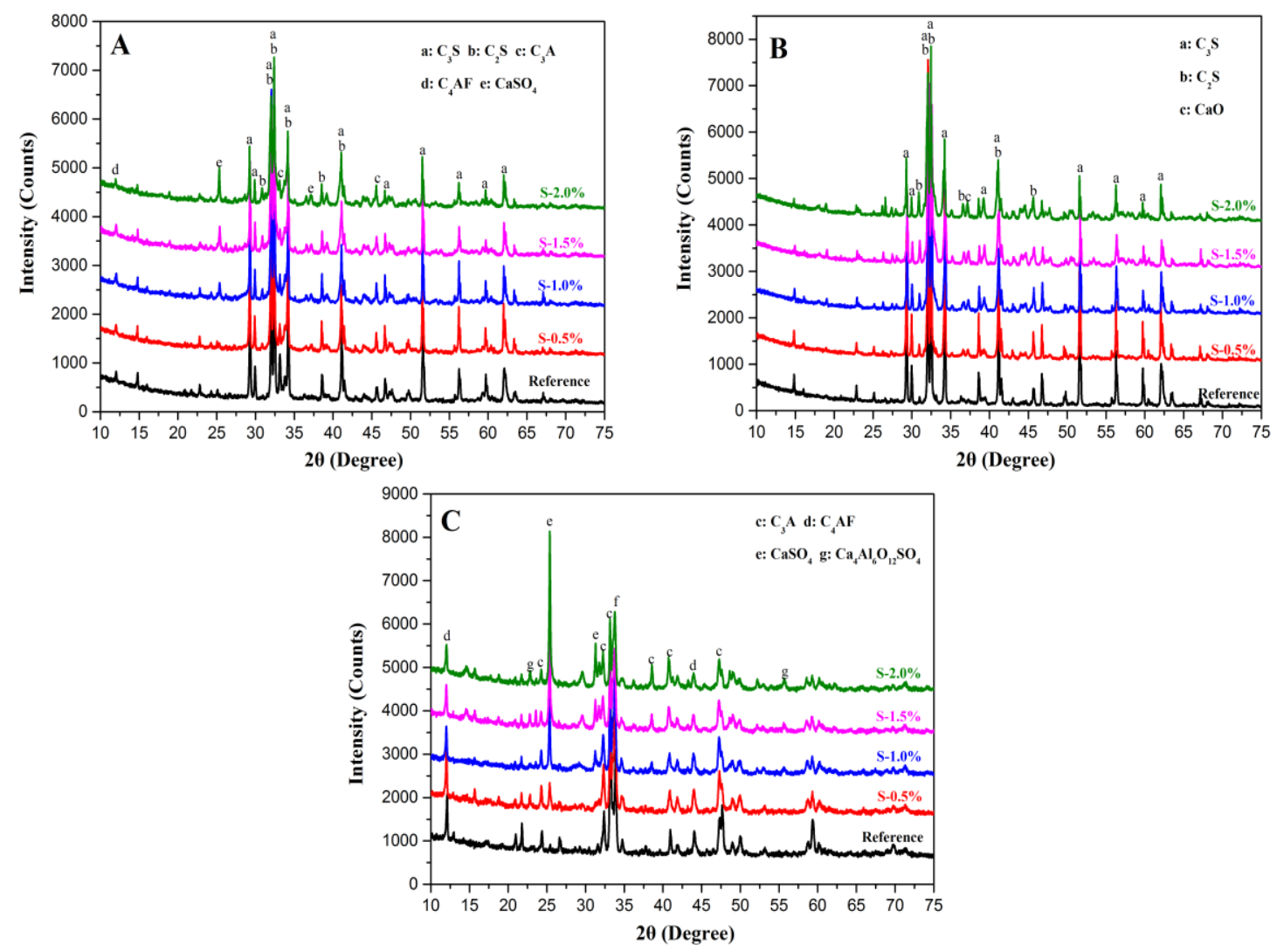

Fig. 7. XRD patterns of $\mathrm{S}_{\mathrm{Pb}-\mathrm{CaSO}-2.0}$ sample sintered at $1450^{\circ} \mathrm{C}$ : A) Clinker; B) Silicate phase; C) Interstitial phase.
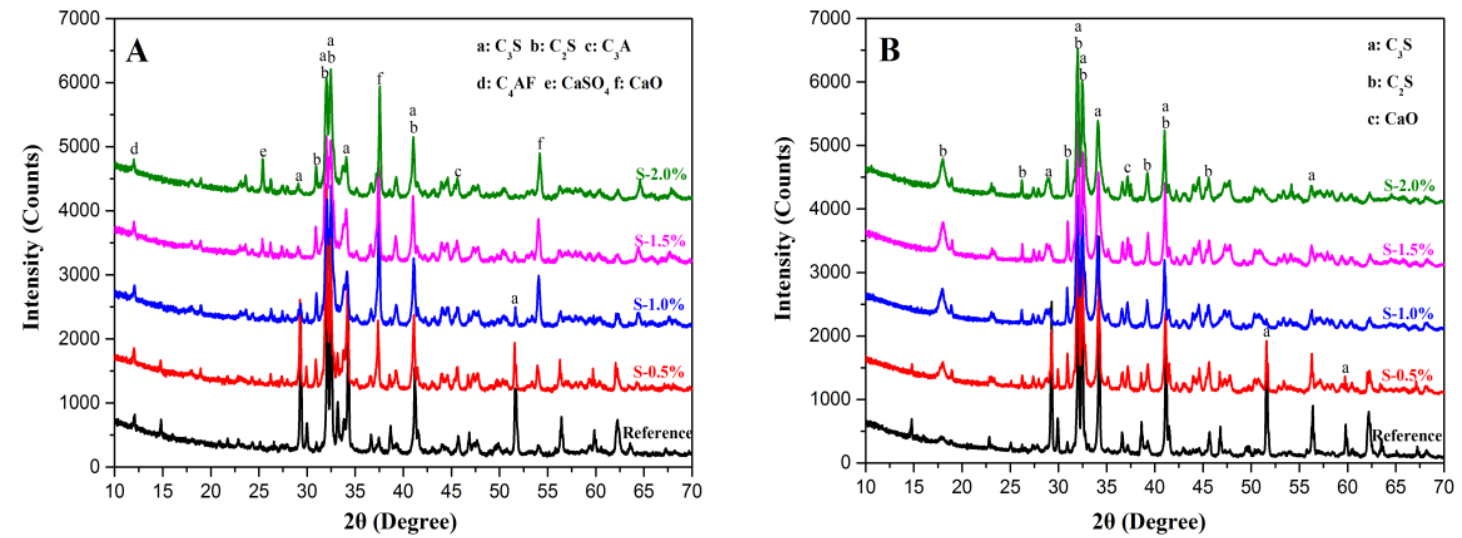


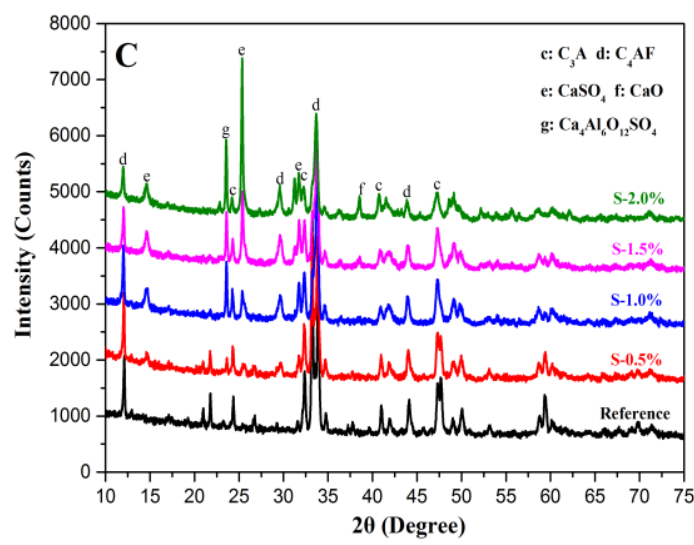

Fig. 8. XRD patterns of $\mathrm{S}_{\mathrm{Cd}-\mathrm{CaSO}-2.0}$ sample sintered at $1450^{\circ} \mathrm{C}$ : A) Clinker; B) Silicate phase; C) Interstitial phase.

\subsection{Distribution of elements in the clinkers}

\subsubsection{EPMA analysis}

The distribution of $\mathrm{Si}, \mathrm{Al}, \mathrm{Cu}, \mathrm{Pb}, \mathrm{Cd}$ and $\mathrm{S}$ in the clinkers are shown in Figures 9-11. Clinker consists of silicate phases $\left(\mathrm{C}_{3} \mathrm{~S}\right.$ and $\left.\mathrm{C}_{2} \mathrm{~S}\right)$ and interstitial phases $\left(\mathrm{C}_{3} \mathrm{~A}\right.$ and $\left.\mathrm{C}_{4} \mathrm{AF}\right)$. It can be seen that the distributions of $\mathrm{Cu}, \mathrm{Pb}$, and $\mathrm{Cd}$ associated with $\mathrm{Al}$ in the clinkers. Therefore, $\mathrm{Cu}, \mathrm{Pb}$, and $\mathrm{Cd}$ were mainly solidified in interstitial phases of the clinker. The $\mathrm{Cu}, \mathrm{Pb}$, and $\mathrm{Cd}$ distributions in the clinker phases were not changed after the $\mathrm{CaSO}_{4} \cdot 2 \mathrm{H}_{2} \mathrm{O}$ and $\mathrm{CaS}$ addition. According to the results from Section 3.3, interstitial phases mainly consist of $\mathrm{C}_{3} \mathrm{~A}, \mathrm{C}_{4} \mathrm{AF}$ and $\mathrm{Ca}_{4} \mathrm{Al}_{4} \mathrm{O}_{12} \mathrm{SO}_{4}$ with the addition of 2.0 wt.\% of S. During clinkerization, the interstitial phases gradually become liquid phase with temperature increasing. The addition of $\mathrm{CaSO}_{4} \cdot 2 \mathrm{H}_{2} \mathrm{O}$ and $\mathrm{CaS}$ increased the amount of the melt and decreased viscosity and surface tension of the melt, accelerating migration of heavy metals in the liquid phase, promoting ion substitution and formation of solid solutions with heavy metals, and possibly the formation of new phases. The 
substitution of $\mathrm{Cu}^{2+}, \mathrm{Pb}^{2+}$, and $\mathrm{Cd}^{2+}$ for $\mathrm{Al}^{3+}$ or $\mathrm{Fe}^{3+}$ in $\mathrm{C}_{4} \mathrm{AF}$ and $\mathrm{Al}^{3+}$ in $\mathrm{C}_{3} \mathrm{~A}$ is possible. Also, formation of different solid solution by isomorphous replacement of $\mathrm{Al}^{3+}$ or $\mathrm{Fe}^{3+}$ $\left(\mathrm{Al}^{3+}-\right.$ ionic radius $0.39-0.54$ and electronegativity $1.61 ; \mathrm{Fe}^{3+}-0.63-0.92$ and 1.83$)$ by $\mathrm{Cu}^{2+}\left(0.57-0.73\right.$ and 1.65), $\mathrm{Pb}^{2+}(0.98-1.49$ and 2.0$)$, and $\mathrm{Cd}^{2+}(0.78-1.31$ and 1.93$)$ is probable.

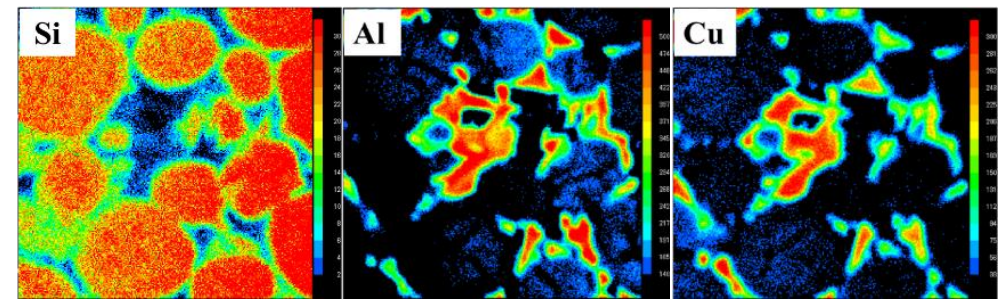

(A)

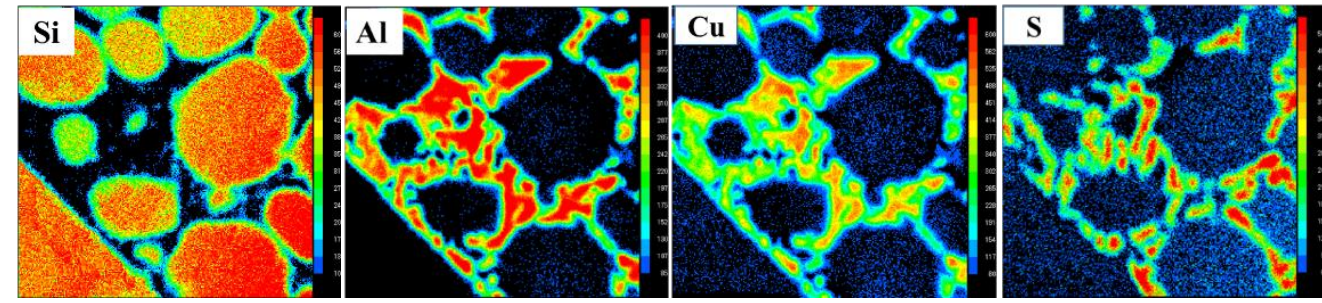

(B)

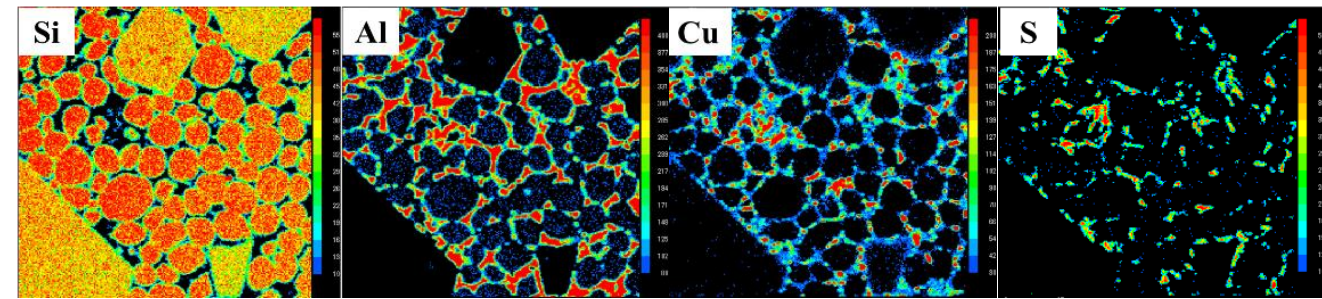

(C)

Fig. 9. An EPMA maps of the $\mathrm{Si}, \mathrm{Al}, \mathrm{Cu}$, and $\mathrm{S}$ distributions in the clinkers: A) $\mathrm{S}_{\mathrm{Cu}-\mathrm{S}-0}$;

B) $\mathrm{S}_{\mathrm{Cu}-\mathrm{CaSO}-2.0}$; C) $\mathrm{S}_{\mathrm{Cu}-\mathrm{CaS}-2.0 \text {. }}$ 


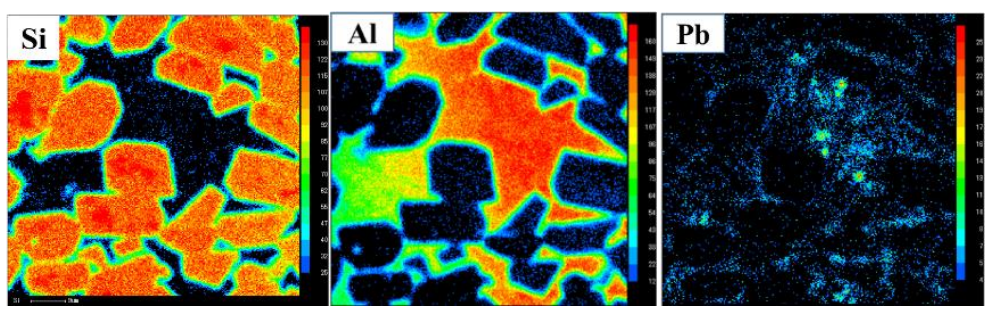

(A)
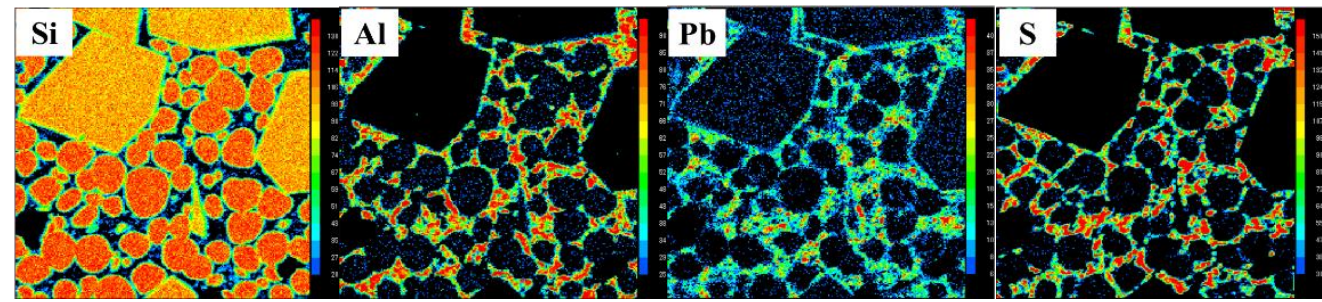

(B)

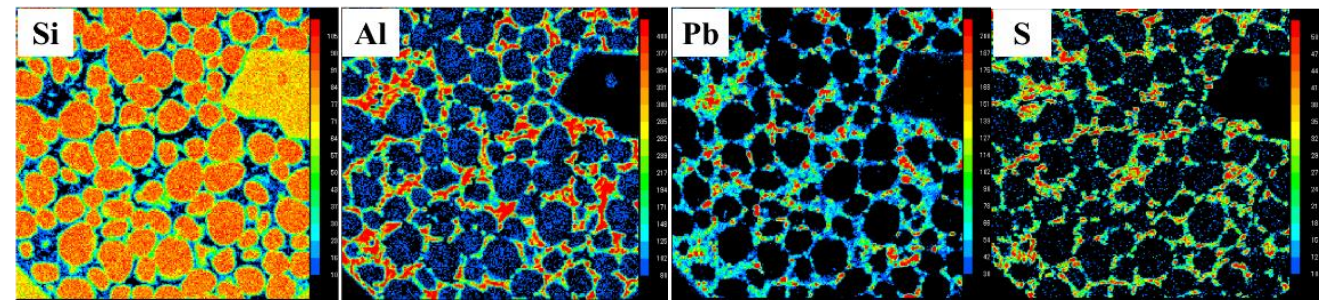

(C)

Fig. 10. An EPMA maps of the $\mathrm{Si}, \mathrm{Al}, \mathrm{Pb}$, and $\mathrm{S}$ distributions in the clinkers: $\mathrm{A}) \mathrm{S}_{\mathrm{Pb}-\mathrm{S} \text { - }}$

0 ; B) $\mathrm{S}_{\mathrm{Pb}-\mathrm{CaSO}} 4-2.0$; C) $\mathrm{S}_{\mathrm{Pb}-\mathrm{CaS}-2.0}$.

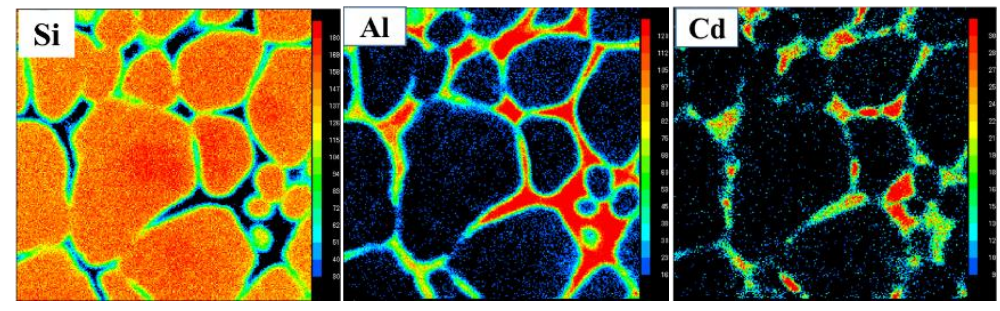

(A) 

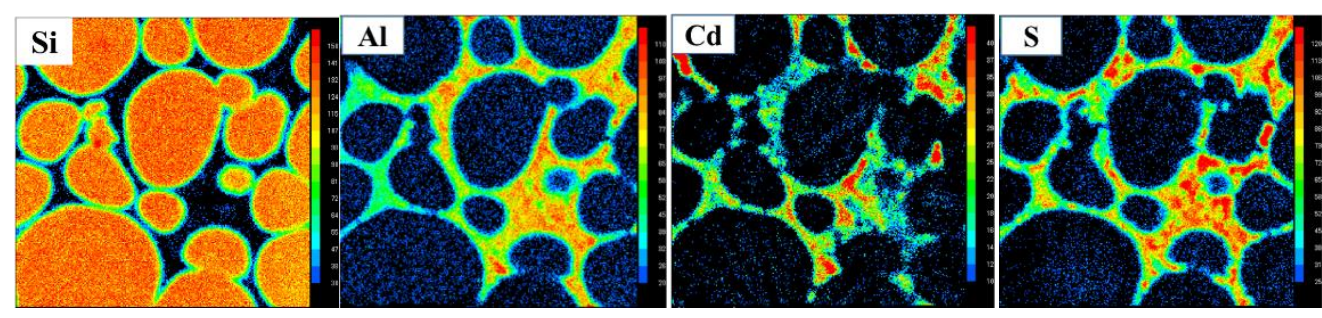

(B)

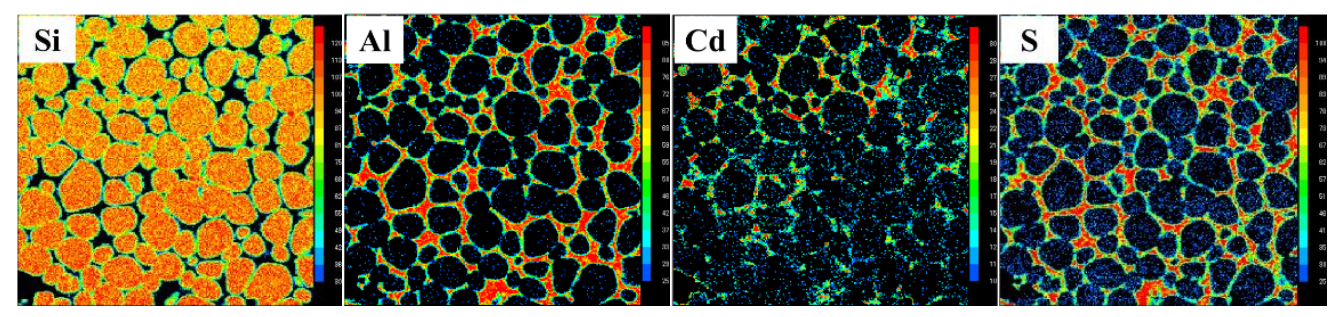

(C)

Fig. 11. An EPMA maps of the $\mathrm{Si}, \mathrm{Al}, \mathrm{Cd}$, and $\mathrm{S}$ distributions in the clinkers: $\mathrm{A}) \mathrm{S}_{\mathrm{Cd}-\mathrm{S}-}$

$$
0 \text {; B) } \mathrm{S}_{\mathrm{Cd}-\mathrm{CaSO} 4-2.0} \text {; C) } \mathrm{S}_{\mathrm{Cd}-\mathrm{CaS}-2.0} \text {. }
$$

\subsubsection{SEM/EDS analysis}

The point chemical analysis of the polished clinker samples sintered at $1450^{\circ} \mathrm{C}$ was carried out to quantitatively investigate the content of $\mathrm{Cu}, \mathrm{Pb}$, and $\mathrm{Cd}$ in silicate and interstitial phases. About fifty spot-analyses were performed for each sample. The results are listed in Table 2. For the sample of $\mathrm{S}_{\mathrm{Cu}-\mathrm{S}-0}$, the content of $\mathrm{Cu}$ is about 0.40 wt. $\%$ and 4.53 wt. $\%$ in silicate phases and interstitial phases, respectively. The addition of 2 wt.\% sulfur as $\mathrm{CaSO}_{4} \cdot 2 \mathrm{H}_{2} \mathrm{O}$ and $\mathrm{CaS}$ had no effect on the solidification of $\mathrm{Cu}$. $\mathrm{In}$ the sample $\mathrm{S}_{\mathrm{Pb}-\mathrm{S}-0}$, the content of $\mathrm{Pb}$ is about $1.98 \mathrm{wt} . \%$ in interstitial phases and cannot be detected in silicate phases. However, the $\mathrm{Pb}$ content is about $1.10 \mathrm{wt} \%$ in silicate phases and 3.65 wt. $\%$ in interstitial phases with the addition of 2 wt. $\%$ of sulfur as $\mathrm{CaSO}_{4} \cdot 2 \mathrm{H}_{2} \mathrm{O}$ and $\mathrm{CaS}$. About 0.26 wt. $\%$ and $2.1 \mathrm{wt} . \%$ of Cd were solidified in silicate 
phases and interstitial phases of $\mathrm{S}_{\mathrm{Cd}-\mathrm{S}-0}$ sample, respectively. With the addition of $\mathrm{CaSO}_{4} \cdot 2 \mathrm{H}_{2} \mathrm{O}$ and $\mathrm{CaS}$, the solidified content of $\mathrm{Cd}$ in silicate and interstitial phases increased in about $35 \%$ and $18 \%$, comparing to the $\mathrm{S}_{\mathrm{Cd}-\mathrm{S}-0}$ sample. The results above confirmed the discussion in Section 3.1 and 3.4.1. For silicate phases of $\mathrm{C}_{2} \mathrm{~S}$ and $\mathrm{C}_{3} \mathrm{~S}$, during clinkerization, the $\mathrm{C}_{3} \mathrm{~S}$ is formed by the combination of $\mathrm{C}_{2} \mathrm{~S}$ and free lime in the liquid phase. $\mathrm{C}_{3} \mathrm{~S}$ cannot massive formation before liquid phase appears. According to the discussion presented above, the addition of sulfur promoted the migration of heavy metals in the liquid phase, that intensified the ion substitution in $\mathrm{C}_{3} \mathrm{~S}$ and $\mathrm{C}_{2} \mathrm{~S}$. Therefore, the incorporation content of $\mathrm{Pb}$ and $\mathrm{Cd}$ in silicate phases increased with the addition of $\mathrm{CaSO}_{4} \cdot 2 \mathrm{H}_{2} \mathrm{O}$ and $\mathrm{CaS}$. The mineralizing effects of $\mathrm{CaSO}_{4} \cdot 2 \mathrm{H}_{2} \mathrm{O}$ and $\mathrm{CaS}$ for the samples added with $\mathrm{Cu}$ is not obvious due to good mineralizing effect.

\section{Table 2}

The average content of heavy metals in silicate and interstitial phases of clinker samples sintered at $1450^{\circ} \mathrm{C}($ wt. \%).

\begin{tabular}{|c|c|c|c|c|c|c|}
\hline \multirow[t]{2}{*}{ ID. } & \multicolumn{3}{|c|}{ Heavy metals in silicate phase } & \multicolumn{3}{|c|}{ Heavy metals in interstitial phase } \\
\hline & $\mathrm{Cu}$ & $\mathrm{Pb}$ & $\mathrm{Cd}$ & $\mathrm{Cu}$ & $\mathrm{Pb}$ & $\mathrm{Cd}$ \\
\hline $\mathrm{S}_{\mathrm{Cu}-\mathrm{S}-0}$ & $0.40 \pm 0.13$ & & & $4.53 \pm 0.26$ & & \\
\hline $\mathrm{S}_{\mathrm{Cu}-\mathrm{CaSO} 4-2.0}$ & $0.37 \pm 0.10$ & & & $4.49 \pm 0.41$ & & \\
\hline $\mathrm{S}_{\mathrm{Cu}-\mathrm{CaS}-2.0}$ & $0.38 \pm 0.12$ & & & $4.28 \pm 0.35$ & & \\
\hline $\mathrm{S}_{\mathrm{Pb}-\mathrm{S}-0.0}$ & & - & & & $1.98 \pm 0.29$ & \\
\hline $\mathrm{SPb}_{\mathrm{Pb}-\mathrm{CaSO} 4-2.0}$ & & $1.10 \pm 0.18$ & & & $3.68 \pm 0.38$ & \\
\hline $\mathrm{SPb}_{\mathrm{Pb}-\mathrm{CaS}-2.0}$ & & $1.07 \pm 0.15$ & & & $3.61 \pm 0.41$ & \\
\hline $\mathrm{S}_{\mathrm{Cd}-\mathrm{S}-0.0}$ & & & $0.26 \pm 0.09$ & & & $2.05 \pm 0.28$ \\
\hline $\mathrm{S}_{\mathrm{Cd}-\mathrm{CaSO} 4-2.0}$ & & & $0.35 \pm 0.11$ & & & $2.42 \pm 0.32$ \\
\hline $\mathrm{S}_{\mathrm{Cd}-\mathrm{CaS}-2.0}$ & & & $0.33 \pm 0.13$ & & & $2.40 \pm 0.29$ \\
\hline
\end{tabular}

Note: -, undetected; \pm , standard deviation. 


\subsection{Effects of sulfur on the chemical forms of $\mathrm{Cu}, \mathrm{Pb}$, and $\mathrm{Cd}$}

According to Herfort et al. [31], at low concentration, heavy metals enter into the structure of the initial phases of the clinker $\left(\mathrm{C}_{3} \mathrm{~S}, \mathrm{C}_{2} \mathrm{~S}, \mathrm{C}_{3} \mathrm{~A}\right.$ and $\left.\mathrm{C}_{4} \mathrm{AF}\right)$ and form different phase assemblages of solid solutions. When the content of heavy metals increases, the presence of new phases might be observed. For example, the formation of $\mathrm{Ca}_{2} \mathrm{CuO}_{3}$ and $\mathrm{CaCu}_{2} \mathrm{O}_{3}$ were identified by $\mathrm{XRD}$ in the clinkers. The scanning electron microscopy images (backscattered electron imaging detector) of the clinker samples sintered at $1450^{\circ} \mathrm{C}$ (Figure 12) show that new phases were formed in the samples with the addition of $\mathrm{CaSO}_{4} \cdot 2 \mathrm{H}_{2} \mathrm{O}$. From the discussion in Section 3.4, sulfur promote $\mathrm{Cu}, \mathrm{Pb}$, and $\mathrm{Cd}$ solidification within interstitial phases forming solid solutions. During that process, the formed solid solutions not only contained heavy metals, but also contained S, that transformed the existence forms of heavy metals in the clinker. The variable compositions of the solid solutions in the interstitial phases were shown in Table 3.
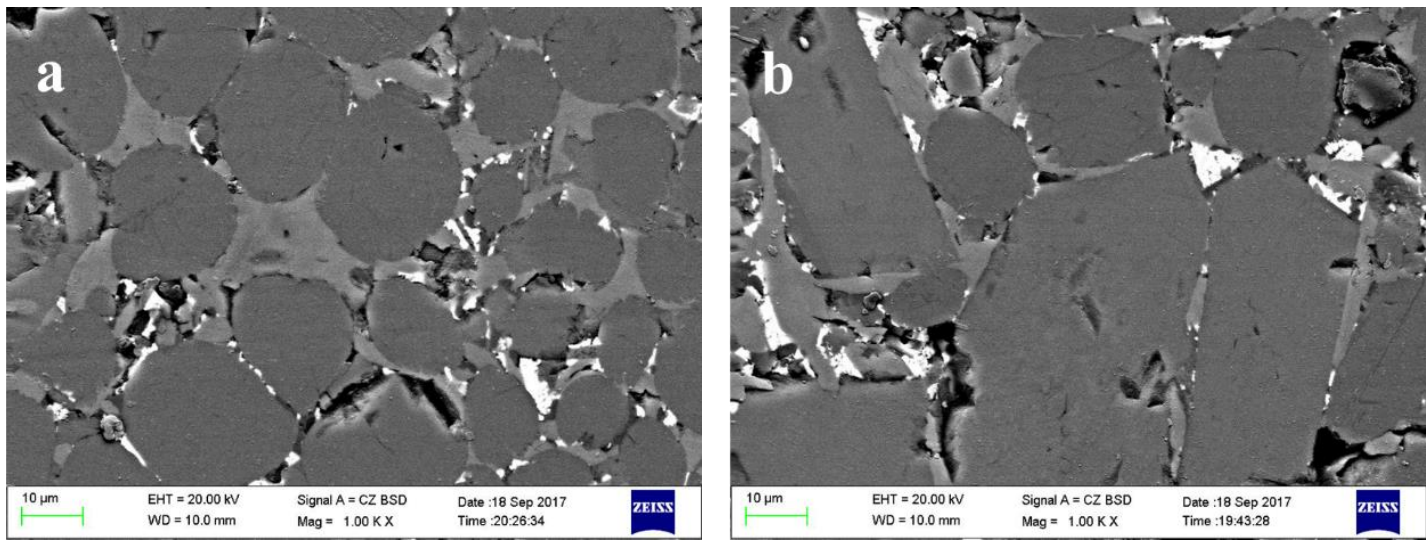

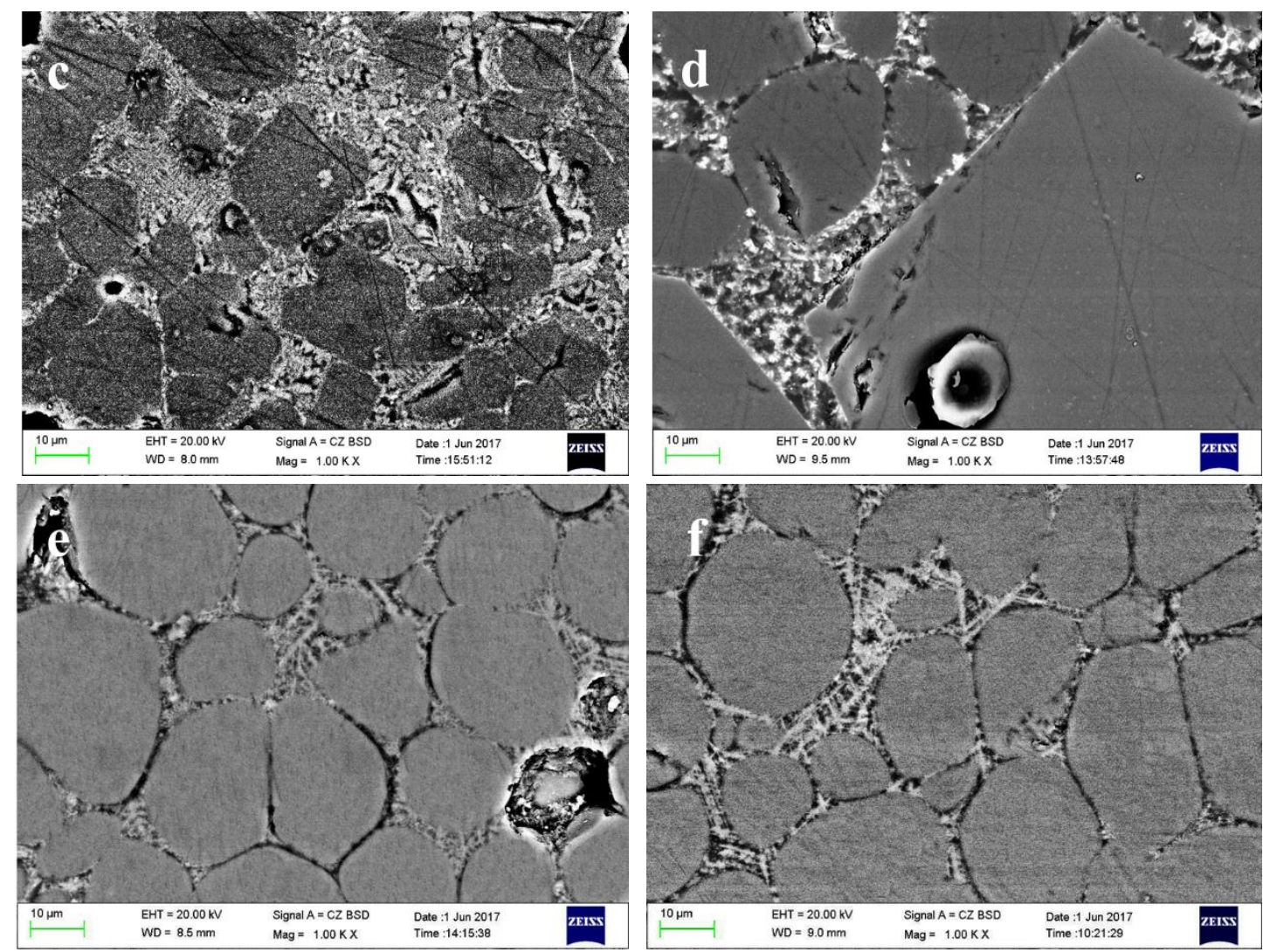

Fig. 12. Scanning electron microscopy images with backscattered electron imaging of

the mineral phases: a) $\mathrm{S}_{\mathrm{Cu}-\mathrm{S}-0}$; b) $\mathrm{S}_{\mathrm{Cu}-\mathrm{CaSO} 4-2.0}$; c) $\mathrm{S}_{\mathrm{Pb}-\mathrm{S}-0}$; d) $\mathrm{S}_{\mathrm{Pb}-\mathrm{CaSO} 4-2.0}$; e) $\mathrm{S}_{\mathrm{Cd}-\mathrm{S}-0}$; f)

\section{$\mathrm{S}_{\mathrm{Cd}-\mathrm{CaSO} 4-2.0}$}

\section{Table 3}

Clinker phase composition based on SEM/EDS analysis (wt.\%) and empirical formula of solid solution.

\begin{tabular}{lllllllll}
\hline Cu-S-2\% & $\mathrm{O}$ & $\mathrm{Al}$ & $\mathrm{Si}$ & $\mathrm{S}$ & $\mathrm{Ca}$ & $\mathrm{Fe}$ & $\mathrm{Cu}$ & Formula composition \\
\hline Interstitial phase & 38.6 & 3.8 & 10.1 & 5.6 & 35.8 & 4.1 & 2.1 & $\mathrm{Ca}_{1.85} \mathrm{Fe}_{0.15} \mathrm{Cu}_{0.07} \mathrm{Al}_{0.29} \mathrm{Si}_{0.75} \mathrm{~S}_{0.36} \mathrm{O}_{5.00}$ \\
Interstitial phase & 38.5 & 3.4 & 3.2 & 10.3 & 37.9 & 4.7 & 2.0 & $\mathrm{Ca}_{1.96} \mathrm{Fe}_{0.17} \mathrm{Cu}_{0.06} \mathrm{Al}_{0.26} \mathrm{Si}_{0.24} \mathrm{~S}_{0.67} \mathrm{O}_{5.00}$ \\
Interstitial phase & 35.5 & 8.6 & 6.7 & 0.29 & 39.8 & 6.1 & 2.9 & $\mathrm{Ca}_{2.24} \mathrm{Fe}_{0.25} \mathrm{Cu}_{0.10} \mathrm{Al}_{0.72} \mathrm{Si}_{0.54} \mathrm{~S}_{0.02} \mathrm{O}_{5.00}$ \\
Interstitial phase & 40.7 & 2.0 & 6.4 & 10.8 & 37.9 & 1.7 & 0.58 & $\mathrm{Ca}_{1.86} \mathrm{Fe}_{0.06} \mathrm{Cu}_{0.02} \mathrm{Al}_{0.14} \mathrm{Si}_{0.45} \mathrm{~S}_{0.66} \mathrm{O}_{5.00}$ \\
Interstitial phase & 37.9 & 6.8 & 5.1 & 4.4 & 36.8 & 6.6 & 2.5 & $\mathrm{Ca}_{1.94} \mathrm{Fe}_{0.25} \mathrm{Cu}_{0.08} \mathrm{Al}_{0.53} \mathrm{Si}_{0.38} \mathrm{~S}_{0.29} \mathrm{O}_{5.00}$ \\
Interstitial phase & 37.8 & 5.9 & 2.9 & 7.8 & 36.4 & 6.0 & 3.2 & $\mathrm{Ca}_{1.92} \mathrm{Fe}_{0.23} \mathrm{Cu}_{0.11} \mathrm{Al}_{0.46} \mathrm{Si}_{0.22} \mathrm{~S}_{0.51} \mathrm{O}_{5.00}$ \\
Interstitial phase & 41.8 & 4.1 & 1.1 & 15.1 & 32.9 & 2.1 & 3.0 & $\mathrm{Ca}_{1.57} \mathrm{Fe}_{0.07} \mathrm{Cu}_{0.09} \mathrm{Al}_{0.29} \mathrm{Si}_{0.07} \mathrm{~S}_{0.90} \mathrm{O}_{5.00}$ \\
Interstitial phase & 37.1 & 8.8 & 1.8 & 4.9 & 32.9 & 11.6 & 3.1 & $\mathrm{Ca}_{1.77} \mathrm{Fe}_{0.45} \mathrm{Cu}_{0.10} \mathrm{Al}_{0.70} \mathrm{Si}_{0.14} \mathrm{~S}_{0.70} \mathrm{O}_{5.00}$ \\
Interstitial phase & 40.9 & 4.7 & 0.84 & 12.7 & 33.7 & 5.3 & 2.0 & $\mathrm{Ca}_{1.65} \mathrm{Fe}_{0.18} \mathrm{Cu}_{0.06} \mathrm{Al}_{0.34} \mathrm{Si}_{0.06} \mathrm{~S}_{0.77} \mathrm{O}_{5.00}$
\end{tabular}




\begin{tabular}{|c|c|c|c|c|c|c|c|c|}
\hline Interstitial phase & 41.6 & 3.2 & 0.49 & 16.2 & 31.3 & 1.9 & 5.4 & $\mathrm{Ca}_{1.51} \mathrm{Fe}_{0.06} \mathrm{Cu}_{0.16} \mathrm{Al}_{0.22} \mathrm{Si}_{0.03} \mathrm{~S}_{0.97} \mathrm{O}_{5.00}$ \\
\hline Interstitial phase & 46.3 & 1.4 & 0.47 & 20.5 & 29.2 & 1.5 & 0.69 & $\mathrm{Ca}_{1.26} \mathrm{Fe}_{0.05} \mathrm{Cu}_{0.02} \mathrm{Al}_{0.09} \mathrm{Si}_{0.03} \mathrm{~S}_{1.1} \mathrm{O}_{5.00}$ \\
\hline $\mathrm{Cu}-\mathrm{S}-0 \%$ & $\mathrm{O}$ & $\mathrm{Al}$ & $\mathrm{Si}$ & $S$ & $\mathrm{Ca}$ & $\mathrm{Fe}$ & $\mathrm{Cu}$ & Formula composition \\
\hline Interstitial phase & 31.3 & 8.3 & 2.7 & & 35.9 & 18.0 & 3.8 & $\mathrm{Ca}_{2.29} \mathrm{Fe}_{0.83} \mathrm{Cu}_{0.15} \mathrm{Al}_{0.78} \mathrm{Si}_{0.25} \mathrm{O}_{5.00}$ \\
\hline Interstitial phase & 31.7 & 11.9 & 0.95 & & 34.8 & 17.8 & 2.8 & $\mathrm{Ca}_{2.19} \mathrm{Fe}_{0.80} \mathrm{Cu}_{0.11} \mathrm{Al}_{1.11} \mathrm{Si}_{0.09} \mathrm{O}_{5.00}$ \\
\hline $\mathrm{Cd}-\mathrm{S}-2 \%$ & $\mathrm{O}$ & $\mathrm{Al}$ & $\mathrm{Si}$ & $\mathrm{S}$ & $\mathrm{Ca}$ & $\mathrm{Fe}$ & $\mathrm{Cd}$ & Formula composition \\
\hline Interstitial phase & 37.1 & 5.2 & 6.9 & 4.4 & 39.8 & 5.1 & 1.5 & $\mathrm{Ca}_{2.14} \mathrm{Fe}_{0.20} \mathrm{Cd}_{0.03} \mathrm{Al}_{0.41} \mathrm{Si}_{0.53} \mathrm{~S}_{0.30} \mathrm{O}_{5.00}$ \\
\hline Interstitial phase & 34.7 & 11.1 & 2.4 & 0.65 & 37.3 & 13.1 & 0.79 & $\mathrm{Ca}_{2.14} \mathrm{Fe}_{0.54} \mathrm{Cd}_{0.02} \mathrm{Al}_{0.95} \mathrm{Si}_{0.20} \mathrm{~S}_{0.05} \mathrm{O}_{5.00}$ \\
\hline Interstitial phase & 32.9 & 11.8 & 2.4 & & 39.8 & 12.4 & 0.80 & $\mathrm{Ca}_{2.42} \mathrm{Fe}_{0.54} \mathrm{Cd}_{0.02} \mathrm{Al}_{1.06} \mathrm{Si}_{0.21} \mathrm{O}_{5.00}$ \\
\hline Cd-S-0\% & $\mathrm{O}$ & $\mathrm{Al}$ & $\mathrm{Si}$ & $\mathrm{S}$ & $\mathrm{Ca}$ & $\mathrm{Fe}$ & $\mathrm{Cd}$ & Formula composition \\
\hline Interstitial phase & 33.1 & 8.1 & 7.4 & & 40.5 & 10.5 & 0.43 & $\mathrm{Ca}_{2.45} \mathrm{Fe}_{0.46} \mathrm{Cd}_{0.01} \mathrm{Al}_{0.72} \mathrm{Si}_{0.64} \mathrm{O}_{5.00}$ \\
\hline Interstitial phase & 34.0 & 8.0 & 8.4 & & 40.6 & 7.8 & 1.3 & $\mathrm{Ca}_{2.38} \mathrm{Fe}_{0.33} \mathrm{Cd}_{0.03} \mathrm{Al}_{0.69} \mathrm{Si}_{0.70} \mathrm{O}_{5.00}$ \\
\hline $\mathrm{Pb}-\mathrm{S}-2 \%$ & $\mathrm{O}$ & $\mathrm{Al}$ & $\mathrm{Si}$ & $S$ & $\mathrm{Ca}$ & $\mathrm{Fe}$ & $\mathrm{Pb}$ & Formula composition \\
\hline Interstitial phase & 27.4 & 9.7 & 2.0 & & 31.3 & 10.1 & 19.6 & $\mathrm{Ca}_{2.28} \mathrm{Fe}_{0.53} \mathrm{~Pb}_{0.28} \mathrm{Al}_{1.05} \mathrm{Si}_{0.20} \mathrm{O}_{5.00}$ \\
\hline Interstitial phase & 31.3 & 10.0 & 2.4 & 2.7 & 40.1 & 10.1 & 3.4 & $\mathrm{Ca}_{2.56} \mathrm{Fe}_{0.46} \mathrm{~Pb}_{0.04} \mathrm{Al}_{0.94} \mathrm{Si}_{0.22} \mathrm{~S}_{0.22} \mathrm{O}_{5.00}$ \\
\hline Interstitial phase & 34.3 & 7.4 & 2.0 & 4.5 & 34.6 & 8.1 & 9.1 & $\mathrm{Ca}_{2.01} \mathrm{Fe}_{0.34} \mathrm{~Pb}_{0.10} \mathrm{Al}_{0.64} \mathrm{Si}_{0.17} \mathrm{~S}_{0.33} \mathrm{O}_{5.00}$ \\
\hline Pb-S-0\% & $\mathrm{O}$ & $\mathrm{Al}$ & $\mathrm{Si}$ & $\mathrm{S}$ & $\mathrm{Ca}$ & $\mathrm{Fe}$ & $\mathrm{Pb}$ & Formula composition \\
\hline Interstitial phase & 30.7 & 14.7 & 1.2 & & 35.3 & 11.9 & 6.2 & $\mathrm{Ca}_{2.29} \mathrm{Fe}_{0.56} \mathrm{~Pb}_{0.08} \mathrm{Al}_{1.42} \mathrm{Si}_{0.11} \mathrm{O}_{5.00}$ \\
\hline Interstitial phase & 29.2 & 15.1 & 2.4 & & 41.2 & 10.8 & 1.3 & $\mathrm{Ca}_{2.82} \mathrm{Fe}_{0.53} \mathrm{~Pb}_{0.02} \mathrm{Al}_{1.53} \mathrm{Si}_{0.23} \mathrm{O}_{5.00}$ \\
\hline Interstitial phase & 29.8 & 14.3 & 2.2 & & 39.7 & 13.1 & 0.84 & $\mathrm{Ca}_{2.66} \mathrm{Fe}_{0.63} \mathrm{~Pb}_{0.01} \mathrm{Al}_{1.43} \mathrm{Si}_{0.21} \mathrm{O}_{5.00}$ \\
\hline Interstitial phase & 31.0 & 13.2 & 3.5 & & 42.2 & 9.5 & 0.54 & $\mathrm{Ca}_{2.71} \mathrm{Fe}_{0.44} \mathrm{~Pb}_{0.01} \mathrm{Al}_{1.26} \mathrm{Si}_{0.32} \mathrm{O}_{5.00}$ \\
\hline Interstitial phase & 31.0 & 13.3 & 3.27 & & 38.5 & 12.2 & 1.8 & $\mathrm{Ca}_{2.47} \mathrm{Fe}_{0.56} \mathrm{~Pb}_{0.02} \mathrm{Al}_{1.27} \mathrm{Si}_{0.30} \mathrm{O}_{5.00}$ \\
\hline
\end{tabular}

\section{Conclusions}

The effects of sulfur on the fate of $\mathrm{Cu}, \mathrm{Pb}$, and $\mathrm{Cd}$ during clinkerization were discussed in this work. The main conclusions can be summarized as follow:

- Sulfur promotes the volatilization of $\mathrm{Pb}$ and $\mathrm{Cd}$ at the temperature from $950^{\circ} \mathrm{C}$ to $1250^{\circ} \mathrm{C}$ by decreasing the melting point of $\mathrm{PbO}$ and $\mathrm{CdO}$. The volatilization ratio of $\mathrm{Cu}$ increased due to its volatilization temperature decreased with sulfur addition at the temperature from $950^{\circ} \mathrm{C}$ to $1450^{\circ} \mathrm{C}$. Sulfur decreased the volatilization temperature of $\mathrm{CuO}, \mathrm{PbO}$, and $\mathrm{CdO}$ for about $40^{\circ} \mathrm{C}, 65^{\circ} \mathrm{C}$, and $35^{\circ} \mathrm{C}$, respectively.

Sulfur acts as a mineralizer/flux changing the thermodynamic stability of $\mathrm{CuO} / \mathrm{PbO} / \mathrm{CdO}$ and, therefore, lowering their volatilization temperature. Sulfur 
increased the solidification ability of clinker decreasing the volatilization ratio of $\mathrm{Pb}$ and $\mathrm{Cd}$ at the temperature of $1350-1450^{\circ} \mathrm{C}$ and $1450^{\circ} \mathrm{C}$, respectively. Both forms of sulfur $\left(\mathrm{CaSO}_{4} \cdot 2 \mathrm{H}_{2} \mathrm{O}\right.$ and $\left.\mathrm{CaS}\right)$ have similar effect on the $\mathrm{Cu} / \mathrm{Pb} / \mathrm{Cd}$ volatilization.

- Sulfur concentrated in interstitial phases of the clinkers mainly as $\mathrm{Ca}_{4} \mathrm{Al}_{6} \mathrm{O}_{12} \mathrm{SO}_{4}$ and $\mathrm{CaSO}_{4}$.

- $\mathrm{Cu}, \mathrm{Pb}$ and $\mathrm{Cd}$ were found to form solid solutions with the variable compositions within interstitial phases of the clinkers. Besides, crystalline phases of $\mathrm{Ca}_{2} \mathrm{CuO}_{3}$ and $\mathrm{CaCu}_{2} \mathrm{O}_{3}$ were identified in the clinkers.

However, the effect of sulfur on the volatilization of $\mathrm{Cu}, \mathrm{Pb}$, and $\mathrm{Cd}$ might be different, if those metals present together in the system (e.g., solid wastes) due to their possible competitive effects. Therefore, further investigation of the element fate during clinkerization in multi-elemental system is required.

\section{Acknowledgements}

This work was supported by the National Natural Science Foundation of China (NSFC, No. 5141101056) and Guangdong science and Technology Department (2014B020216002).

\section{References}

[1] China Environmental State Bulletin: 2016.

[2] China Annual Report of Comprehensive Utilization of Resources: 2015.

[3] S. Bozkurt, L. Moreno, I. Neretnieks, Long term processes in waste deposits, Sci. 
Total Environ. 250 (2000) 101-121.

[4] M.J. Quina, E. Bontempi, A. Bogush, S. Schlumberger, G. Weibel, R. Braga, V. Funari, J. Hyks, E. Rasmussen, J. Lederer, Technologies for the management of MSW incineration ashes from gas cleaning: new perspectives on recovery of secondary raw materials and circular economy, Sci. Total Environ. 635 (2018) 526-542.

[5] P. Xue, A. Xu, D. He, Q. Yang, G. Liu, Fredrik Engstrom, Bo Bjorkman, Research on the sintering process and characteristics of belite sulphoaluminate cement produced by BOF slag, Constr. Build. Mater. 122 (2016) 567-576.

[6] P.E. Tsakiridis, M. Samouhos, M. Perraki, Valorization of Dried Olive Pomace as an alternative fuel resource in cement clinkerization, Constr. Build. Mater. 153 (2017) $202-210$.

[7] M. Huang, X. Ying, D. Shen, H. Feng, N. Li, Y. Zhou, Y. Long, Evaluation of oil sludge as an alternative fuel in the production of Portland cement clinker, Constr. Build. Mater. 152 (2017) 226-231.

[8] B. Das, S. Prakash, P.S.R. Reddy, V.N. Misra, An overview of utilization of slag and sludge from steel industries, Resour. Conserv. Recy. 50 (2007) 40-57.

[9] D. Yan, K.H. Karstensen, Q. Huang, Q. Wang, M. Cai, Coprocessing of industrial and hazardous wastes in cement kilns: A review of current status and future needs in China, Environ. Eng. Sci. 27 (2010) 37-45.

[10] N. A. Madlool, R. Saidur, M.S. Hossain, N.A. Rahim, A Critical review on energy use and savings in the cement industries, Renew. Sust. Energ. Rev. 15 (2011) 20-42.

[11] R.K. Gupta, D. Majumdar, J.V. Trivedi, A.D. Bhanarkar, Particulate matter and 
elemental emissions from a cement kiln, Fuel Process. Technol. 104 (2012) 343-351.

[12] B. Cristina, G. Gisela, A. Sofia, P. Pedro, M. Cristina, C. Otilia, Biomonitoring spatial and temporal impact of atmospheric dust from a cement industry, Environ. Pollut. 151 (2008) 292-299.

[13] P. Ch. Hsiau, S.L. Lo, Extractabilities of heavy metals in chemically-fixed sewage sludges, J. Hazard. Mater. 58 (1998) 73-82.

[14] A.P. Ghorpade, M.G. Ha, W.H. Choi, J.Y. Park, Combined calcium sulfoaluminate and ordinary portland cement/Fe(II) system for enhanced dechlorination of trichloroethylene, Chem. Eng. J. 231 (2013) 326-333.

[15] P. Tang, Y.C. Zhao, D.Z. Chen, F.Y. Xia, Volatility of heavy metals during incineration of tannery sludge in the presence of chlorides and phosphoric acid, Waste Manage. Res. 26 (2008) 369-376.

[16] Y. Ji, K. Yang, D. Xu, R. Zhou, Y. Sun, Study on Sulfur Cycle of Dynamic Equilibrium in NSP Cement Kiln System, Bull, Chinese Ceram. Soc. 30 (2011) 10231028.

[17] C. Chan, C.Q. Jia, J.W.Graydon, D.W. Kirk, The behaviour of selected heavy metals in MSW incineration electrostatic precipitator ash during roasting with chlorination agents, J. Hazard. Mater. 50 (1996) 1-13.

[18] S.R. Smith, A critical review of the bioavailability and impacts of heavy metals in municipal solid waste composts compared to sewage sludge, Environ. Int. 35 (2009) $142-156$.

[19] B. Nowak, A. Pessl, P. Aschenbrenner, P. Szentannai, H. Mattenberger, H. 
Rechberger, G. Kakali, G. Parissakis, D. Bouras, A study of the burnability and the phase formation of PC clinker containing Cu oxide, Cem. Concr. Res. 26 (1996) 14731478.

[20] B. Nowak, S.F. Rocha, P. Aschenbrenner, H. Rechberger, F. Winter, Heavy metal removal from MSW fly ash by means of chlorination and thermal treatment: Influence of the chloride type, Chem. Eng. J. 179 (2012) 178-185.

[21] K. Kolovos, S. Tsivilis, G. Kakali, The effect of foreign ions on the reactivity of the $\mathrm{CaO}-\mathrm{SiO}_{2}-\mathrm{Al}_{2} \mathrm{O}_{3}-\mathrm{Fe}_{2} \mathrm{O}_{3}$ system, Cem. Concr. Res. 32 (2002) 463-469.

[22] I. Jawed, J. Skalny, Alkalies in cement: a review, Cem, Concr. Res. 7 (1977) 719730.

[23] A.A. Bogush, J.A. Stegemann, I. Wood, A. Roy, Element composition and mineralogical characterisation of air pollution control residue from UK energy-fromwaste facilities, Waste Manage. 36 (2015) 119-129.

[24] L. Nirut, R.M. Anthony, M. Natt, Utilization of cathode ray tube waste: Encapsulation of $\mathrm{PbO}$-containing funnel glass in Portland cement clinker, J. Environ. Manage. 117 (2013) 180-186.

[25] S. Yu, B. Zhang, J. Wei, T. Zhang, Q. Yu, W. Zhang, Effects of chlorine on the volatilization of heavy metals during the co-combustion of sewage sludge, Waste Manage. 62 (2017) 204-210.

[26] J. Han, M. Xu, H. Yao, Influence of calcium chloride on the thermal behavior of heavy and alkali metals in sewage sludge incineration, Waste Manage. 28 (2008) 833839. 
[27] H.C. Yang, Y.C. Seo, J.H. Kim, H.H. Park, Y. Kang, Vaporization characteristics of heavy metal compounds at elevated temperatures, Korean J. Chem. Eng. 11 (1994) $232-238$.

[28] H.F.W. Taylor, Cement Chemistry, second ed., Thomas Telford, New York, 1997. [29] W.A. Gutterdge, On the dissolution of the interstitial phases in Portland cement, Cem. Concr. Res. 19 (1979) 319-324.

[30] K. Kolovos, S. Tsivilis, G. Kakali, SEM examination of clinkers containing foreign elements, Cem. Concr. Compos. 27 (2005) 163-170.

[31] D. Herfort, G.K. Moir, V. Johansen, F. Sorrentino, H.B. Arceo, The chemistry of Portland cement clinker, Adv. Cem. Res. 22 (2010) 187-194.

[32] S. Horkoss, R.Lteif, T. Rizk, Influence of the clinker $\mathrm{SO}_{3}$ on the cement characteristics, Cem. Concr. Res. 41 (2011) 913-919.

[33] S. Telschow, F. Frandsen, K. Theisen, K. Dam-Johansen, Cement Formation. A Success Story in a Black Box: High Temperature Phase Formation of Portland Cement Clinker. Ind. Eng. Chem. Res. 51 (2012) 10983-11004.

[34] H.F.W. Taylor, Distribution of sulfate between phases in Portland cement clinkers, Cem. Concr. Res. 29 (1999) 1173-1179.

[35] D. Herfort, G.K. Moir, V. Johansen, F. Sorrentino, H.B. Arceo, The chemistry of Portland cement clinker, Adv. Cem. Res. 22 (2010) 187-194.

[36] F. Wang, D. Shang, M. Wang, S. Hu, Y. Li, Incorporation and substitution mechanism of cadmium in cement clinker, J. Clean. Prod. 112 (2016) 2292-2299.

[37] J. Wu, X. Yang, L. Yang, X. Kong, Z. Zhang, X. Wang, Study on oxidation 
behaviors of CaS, Inorg. Chem. Ind. 8 (2015) 26-29.

[38] H. Xiao, J. Zhou, J. Liu, H. Fan, J. Cheng, K. Cen, Research on CaS oxidation reaction with thermogravimetric analysis, J. Zhejiang Univ. 40 (2006) 982-990.

[39] G. Zhao, J. Lin, C. Mei, K. Han, Study on formation process of sulphoalum inate calcium during high temperature desulfuration, J. Fuel Chem. Technol. 34 (2006) 665669.

[40] S. Ma, X. Shen, L. Chen, Research on the Decomposition Kinetics of Calcium Sulphoaluminate, Bulletin of the Chinese Ceramic Society, 29 (2010) 701-704. 